\title{
Política indigenista argentina: una construcción inconclusa
}

\section{Diana Lenton}

\section{(2) OpenEdition \\ 1 Journals}

Edição electrónica

URL: http://journals.openedition.org/aa/781

DOI: 10.4000/aa.781

ISSN: 2357-738X

\section{Editora}

Programa de Pós-Graduação em Antropologia Social (UnB)

\section{Edição impressa}

Data de publição: 1 junho 2010

Paginação: 57-97

ISSN: 0102-4302

\section{Refêrencia eletrónica}

Diana Lenton, «Política indigenista argentina: una construcción inconclusa», Anuário Antropológico [Online], v.35 n.1 | 2010, posto online no dia 07 outubro 2015, consultado o 28 abril 2021. URL: http:// journals.openedition.org/aa/781; DOI: https://doi.org/10.4000/aa.781

\section{(c) $)(1)(9$}

Anuário Antropológico is licensed under a Creative Commons Atribuição-Uso Não-Comercial-Proibição de realização de Obras Derivadas 4.0 International. 


\section{Política indigenista argentina: una construcción inconclusa*}

Diana Lenton

Universidad de Buenos Aires y CONICET

\section{Introducción}

Pensar la política indigenista como objeto de investigación es una tarea especialmente difícil en Estados como la Argentina, donde la negación de la propia existencia del objeto de referencia de tal política ha sido un tópico, cuando no una meta, reiterada en el discurso político y en el sentido común de los últimos ciento veinte años. El convencimiento, resultado de una política de educación cívica consciente, de que "los argentinos venimos de los barcos", y el proyecto de un "crisol de razas" amable, pero limitado a ciertos genotipos, hicieron parecer innecesaria la planificación o la reflexión sobre una realidad indígena que no fuera su próxima extinción o integración o miscigenación. Por eso, parece lógico que la normativa argentina sobre Pueblos Originarios haya sido durante la mayor parte del siglo XX, y aun hoy en gran medida, errática e inorgánica, y más aún, ignorada por la mayor parte de la clase política.

Recién a partir del retorno de la democracia en la década de 1980, y al calor de una intensa demanda por la extensión de los derechos humanos, el Congreso Nacional sancionó su primera "Ley 23302 de Política Indígena y Apoyo a las Comunidades Aborígenes”, en respuesta a la presión tanto de la jurisprudencia internacional como de la movilización interna de la militancia indígena.

En la Argentina, el modo de nombrar a los hombres y mujeres descendientes de aquellos que habitaban el continente antes de la invasión europea es en sí mismo objeto de disputas. Indios, indígenas, aborígenes, Pueblos Originarios son apelativos originados en diferentes paradigmas, y por ende gozan de diferentes niveles de aceptación tanto por parte de la militancia indigenista como de la "corrección política" ciudadana. A los fines de este trabajo optaremos por la terminología que goza actualmente de mayor aceptación - Pueblos Originarios - o la más recurrente en las fuentes documentales - indígenas - aun cuando las otras apelaciones pueden ser adecuadas en determinados contextos. ${ }^{1}$ La Ley 23302 mencionada exhibe esta indecisión terminológica, indudablemente índice de otras ambigüedades, desde su mismo título, que refiere como indígena a la política estatal, pero aborígenes a su objeto de referencia. 
De manera similar, el término "indigenista" es objeto de discusión, dado que en su origen refería a un campo de interés valorativo y especialmente afectivo, surgido en ciertas áreas de la intelectualidad latinoamericana. ${ }^{2}$ Decantó entonces en el sentido común argentino como calificativo de políticas o discursos "a favor de los indios / indígenas / aborígenes etc.”, atravesando otras divisiones ideológicas. Algunas posiciones consideraron necesario crear otros conceptos, que enfatizaran cuándo la posición "indigenista" partía de los propios "indígenas", para la cual, en la década de 1980 se acuñó el término indianista, reservando el indigenismo para el "blanco amigo de los indios".

Sin embargo, en mi trabajo de investigación propongo adoptar el término política indigenista para referirme a toda política de Estado referida a los que hoy llamamos Pueblos Originarios, independientemente de su contenido axiológico. En este sentido, la política indigenista argentina abarca no sólo las últimas normativas reconocedoras de derechos colectivos de los Pueblos Originarios, sino también, por ejemplo, las históricas leyes 215/1867 y 947/1878 que autorizaron la llamada “Campaña del Desierto”. De esta manera, evito llamar política indígena a la política de Estado (pese a que suele ser el término utilizado por el discurso estatal), para diferenciarla de la política indígena en tanto política de representación y estrategias de participación y/o autonomización de las organizaciones de militancia y/o colectivos de pertenencia de los Pueblos Originarios.

Dadas estas aclaraciones, podemos afirmar entonces que la política indigenista argentina se tensiona entre la presunción de la inexistencia - por diferentes causas - de Pueblos Originarios en su cuerpo político, asunción que se refleja en la inorganicidad de la escasa normativa existente, y una más o menos reciente voluntad pluralista explícita que pugna por crear colectivos y representaciones estatalmente patrocinados.

Esta característica no es excluyente de la Argentina. Como afirma Lins Ribeiro (2004:169 y ss.), Argentina y Brasil se construyeron como Estado-nación a partir de paradigmas y experiencias históricas que aparecen como opuestas - la economía especializada de plantación en Brasil, la periferia indígena vs. el centralismo pro europeo en Argentina - y dicha oposición se traslada a la construcción de las relaciones entre el Estado-nación y sus otros internos. Sin embargo, creo que es justo admitir que si bien tales imágenes son sin duda hegemónicas en el trazo grueso de la etnicidad en ambas repúblicas, a la hora de pergeñar su política indigenista hay correspondencias que valen la pena considerar, acercando a ambas experiencias nacionales más de lo que sugiere la oposición tropicalismo / europeísmo que este autor identifica como proyectos respectivos de las elites fundadoras, luego ampliamente difundidos hacia el interior y el exterior de sus colectivos. 
En Argentina, la "Conquista del Desierto" no terminó con la ocupación militar de los territorios indígenas, sino que la misma estuvo estrechamente ligada a la economía de plantación en las provincias del norte, que se convirtió en destino privilegiado de los pueblos vencidos por los avances del ejército y el capital, ${ }^{3}$ y que constituyó un modelo de economía regional posible, ${ }^{4}$ cuyo auge coincidente con la "Organización Nacional" ${ }^{5}$ no evitó la abundancia de debates sobre sus consecuencias sociales, políticas y éticas. ${ }^{6}$

Por otra parte, la narrativa del Desierto no fue exclusiva de la Argentina, sino que también el poder hegemónico en otros Estados en consolidación recurrió al mismo tropo para legitimar su expansión territorial. Alcida Ramos (2009) analiza la significación del deserto en la constitución ideológica del Brasil y su aboriginalidad. El deserto literario brasileño del siglo XIX significaba, al igual que en Argentina, "vazio humano", "vazio demografico", "[...] na ausência de branco emprendedor”. ${ }^{7}$ Como explica Alicia Barabas (2000:5), para otros contextos continentales, estar habitado por indios era simplemente confirmar el carácter salvaje y vacío de un espacio llamado "desierto".

En Argentina la idea de civilización fue adoptada por las elites - porteñas y provincianas - a partir de la Generación del '37, cuando se diseñó por oposición al desierto tanto como a la barbarie. Debe notarse la diferencia de matiz entre ambas entidades oponentes: mientras que la idea de barbarie implica la existencia de una diversidad contra la cual lucha la empresa civilizadora, la idea de desierto instala la noción de una frontera entre el nosotros y la nada, fortaleciendo las posibilidades de intervención de posiciones que extreman la intolerancia. En este sentido, la vieja premisa alberdiana Gobernar es poblar debe interpretarse como un mandato que no se limita al aumento de la población preexistente, que los intelectuales de su tiempo menospreciaban, sino que se dirige al establecimiento en los espacios “desiertos" de una clase de habitantes más cercana al paradigma liberal de ciudadano aceptable. ${ }^{8}$

Sin embargo no debe creerse que la representación del desierto como medio -natural o social - era unívoca. Algunos contemporáneos acusaban al oficialismo roquista de promover la idea de desierto con fines políticos - utilización que, según Grüner (2003:347), es tributaria de una larga tradición utópica o contrautópica remontable hasta la cultura política clásica. Por ejemplo, el Senador autonomista correntino Santiago Baibiene, procurando infructuosamente rebatir el proyecto oficial de territorialización de Misiones, acusaba al P.E.N. en 1881 de fomentar una concepción errónea del territorio que hoy constituye la provincia de Misiones, al calificarla de “desierto" para justificar su secesión de la provincia de Corrientes y su apropiación por el gobierno federal, y ocultar el exterminio de opositores políticos, el robo, la destrucción y 
la especulación en tierras. Denunciaba de paso que la intervención nacional "se dedica a matar a esos pobres indios, peones laboriosos en los obrajes de madera, proveedores pacíficos [agrícolas] [...] acusándolos de malones inexistentes" (Diario de Sesiones del Senado de la Nación, sesión del 17/9/1881).

Es cierto, como sugiere el ensayo de Lins Ribeiro (2004), que la narrativa de la “Organización Nacional” argentina combina temporal y espacialmente la presencia de una elite europeizada y con características que la hicieron única con una fase de frontera económica en expansión, que involucró "la incorporación de nuevos territorios a mercados nacional e internacionalmente integrados, con nuevos ciclos de producción de riqueza asociados a estos frentes”, características que no volvieron a producirse en el país. ${ }^{9}$

Tanto en Brasil como en Argentina, el componente poblacional aborigen es visto como minoritario y "geográficamente alejado" de los centros de decisión, a diferencia de otras naciones del continente. En ambas, por otra parte, esta visión minimizadora del componente aborigen choca con los escasos datos cuanti y cualitativos, que suelen sorprender a los ciudadanos - especialmente en Argentina con presencias indígenas insospechadas. Me refiero tanto a la sorpresa que suelen manifestar los argentinos frente a la mera existencia de indios en el territorio y que no provengan de países limítrofes ("todavía”, suele decirse, con toda la carga evolutiva que ello implica), como a la que le sigue a la constatación del alto grado de mestizaje biológico a despecho de las promesas de blanqueamiento por vía de la que resultó no tan mayoritaria inmigración europea ${ }^{10} \mathrm{y}$, en un plano ya no cuantitativo, a la problemática aparición en la escena política de identidades que se creían extintas. ${ }^{11}$

Me atrevería a afirmar en este punto que el modelo de la economía de plantación que se corresponde con un desierto amazónico con indios salvajes y el del desierto conquistado a pueblos evanescentes son dos caras de una misma construcción de aboriginalidad (Briones, 1998a), en gran medida compartida por Brasil y Argentina, aun cuando aparenten negarse mutuamente en la superficie.

Podemos afirmar que la aboriginalidad tanto en Argentina como en Brasil se ha formado a partir de la construcción especular de una noción de aborigen / indígena en contraste con las imágenes hegemónicas de la nación en sus variaciones históricas. ${ }^{12}$ En palabras de Alicia Barabas - siguiendo a Alcida Ramos (1998:207) - "los indios siempre han sido una reserva inagotable de imágenes manipulables y el imaginario que trata sobre ellos es tan rico como contradictorio, ya que puede concebirlos como hijos del paraíso o como salvajes culpables del subdesarrollo nacional” (Barabas, 2000:1). 
No obstante la constatación de la estrecha vinculación entre contexto histórico y construcción ideológica de sujetos políticos, y basándonos en que el Estado produce alteridades concretas, vale la pena preguntarse, siguiendo a Comaroff y Comaroff (1992), acerca de la materialidad de las ideas, o el por qué ciertas representaciones perduran y van adquiriendo "vida propia" más allá de las condiciones que les dieron origen. La perdurabilidad de representaciones - imágenes y discursos - cuya explicación ancla en contextos ya pasados aun cuando muchas veces recreados (Briones, 1998a), requiere visualizar la producción de la etnicidad en relación a procesos de inclusión y exclusión y de promoción de "otros internos" en el marco de la puja hegemónica (cfr. Briones, 1995; Briones \& Lenton, 1997). De este modo, la investigación de la genealogía ${ }^{13}$ de las concepciones de aboriginalidad resulta inseparable de la indagación de su pervivencia o su negación en el presente. Y de este modo también, ahondar en el tratamiento que estos Estados-naciones dan a sus alteridades implica develar la construcción profunda y perdurable de sus nacionalidades.

\section{Manifestaciones somáticas de la aboriginalidad y la sombra del genocidio}

En Argentina, como ya anticipamos, uno de los más clásicos tópicos del discurso que toma como objeto de referencia a los Pueblos Originarios es aquél que habla de su acabamiento, concretado o próximo a realizarse. Este topos, que niega la necesidad y aun la posibilidad de una política indigenista, es sin embargo un elemento recurrente en muchos de los textos que componen la propia normativa indigenista, y es parte del sentido común argentino, que se evidencia en la sorpresa generalizada cuando la extinción es refutada (Briones, 2004:73; Quijada, 2000). Si es cierto que fue abundante en los discursos generados inmediatamente después del cuerpo de políticas indigenistas englobadas en la llamada Conquista del Desierto, ${ }^{14}$ a fines del siglo XIX - ratificando una política que niega la pertinencia del reconocimiento de la diversidad a futuro - también lo es que quedó como recurso explicativo - con distintas orientaciones valorativas - en los discursos que, décadas más tarde, comienzan a constatar la supervivencia de indios o descendientes de indios (Figura 1).

Estos discursos de la supervivencia se orientan en dos direcciones: aquellos que constatan la presencia del elemento indígena en la sangre de una parte del "pueblo nativo”, y aquellos que constatan también la presencia de elementos culturales y organizacionales vitales y pasibles de ser "aún" reconocidos como originarios. En ambos casos, aun cuando no se hubiera llegado a negar absolutamente esa persistencia, la novedad reside en el descubrimiento de proporciones mayores a las aceptadas (Figura 2). 


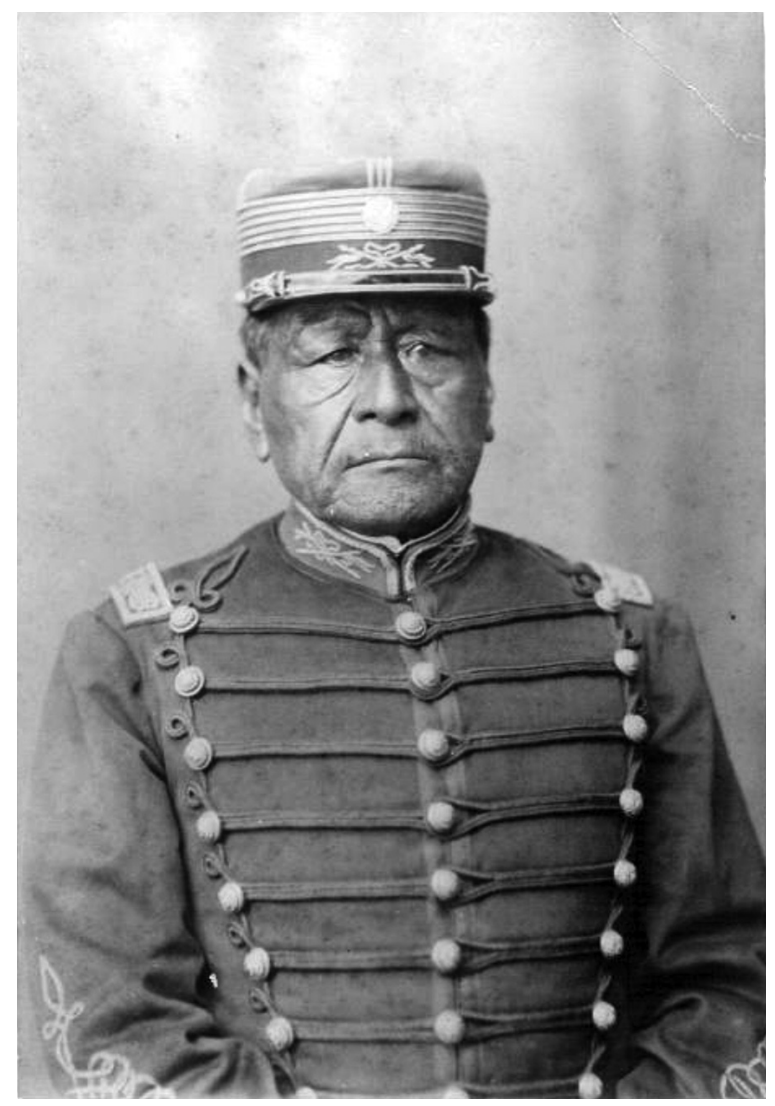

\section{Figura 1}

Manuel Namuncurá, uno de los principales logkos (jefes) del mundo indígena independiente, fotografiado con el uniforme militar argentino, que vistió luego de su derrota en 1884. (Fuente: Archivo General de la Nación.)

Entre los destinos posibles para los miles de indígenas vencidos en las campañas militares de fines del siglo XIX se hallaba, para los varones, el servicio en el Ejército o la Marina o el trabajo en haciendas, ingenios u obrajes; para las mujeres y los niños, el servicio doméstico rural o urbano. En la mayoría de los casos, la separación familiar y el repartimiento eran precedidos de largos períodos de concentración en Martín García, Retiro (Bs. As.), Valcheta, Chichinales (Río Negro), Rodeo del Medio (Mendoza), u otros puntos del país. En pocos casos, quedaban confinados en misiones religiosas y, en muchos menos, llegaban a obtener la parcela de tierra necesaria para iniciar la ansiada reconstrucción de una vida autónoma, aunque bajo vigilancia militar. 


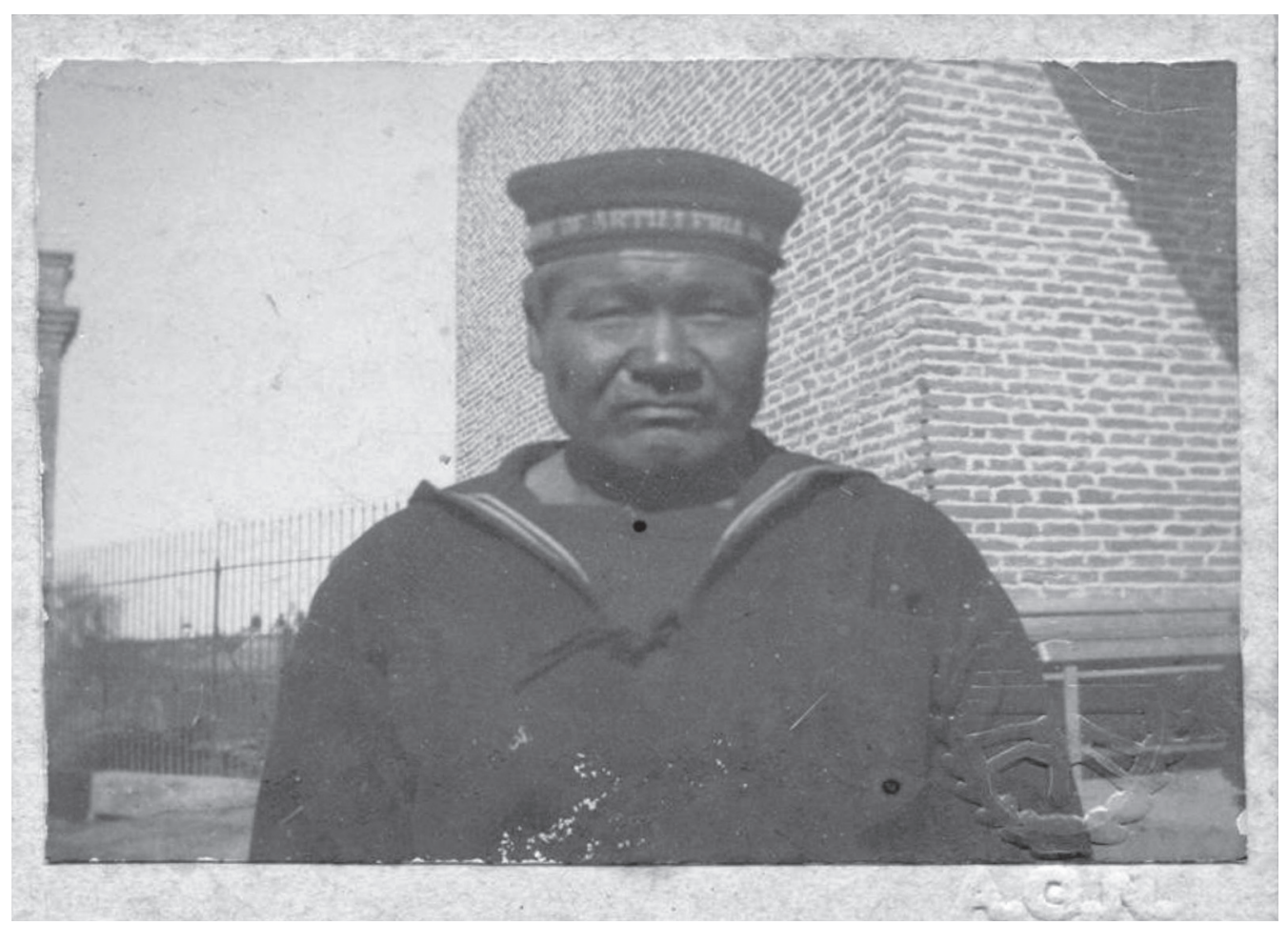

\section{Figura 2}

Un anónimo joven Selk'nam destinado al servicio en la Armada, ca. 1890. (Fuente: Archivo General de la Nación.)

En la primera dirección, se ordenan las argumentaciones que tienden a la asimilación de este "pueblo", para el cual se ensayan eufemismos varios, dentro del enorme crisol de la argentinidad. No se espera por lo tanto el diseño de políticas específicas, salvo el refuerzo de algunas instituciones - escuelas especiales, patronatos, campañas antialcohol - que permitieran salvar la brecha entre el deseo de modernidad y la dificultad esencial de estos ciudadanos carentes.

En la segunda dirección, se impone el debate sobre las posibilidades de una política indigenista de largo plazo. Sin embargo, la conjunción del éxito hegemónico del discurso de la extinción sumado a los nuevos sentidos de corrección política que desaconsejan el uso de diacríticos en torno a lo racial en pro de una sociedad supuestamente igualitaria, y a la incidencia de ciertos discursos emergentes sobre la nación mestiza, obturaron por largas décadas la posibilidad de un reconocimiento definitivo, desde el Estado, de la persistencia y perdurabilidad de los pueblos originarios. Tiene que ver con esta dificultad el persistente monismo jurídico que impone la negación de la diversidad en pos de la igualdad ante la ley. ${ }^{15}$ 
Lejos de ser un accidente histórico, el genocidio ${ }^{16}$ es un factor que por su sistematicidad y extensividad opera de trasfondo de la política indigenista y es central para entender el acallamiento de la agentividad indígena aún en nuestros días. Es socio del silencio y la autocensura en el seno de los Pueblos que lo sufrieron (Trinchero, 2005) y, especialmente, es la base sobre la que se construyeron las instituciones que en adelante regularon no sólo la política interétnica, sino la política social más amplia (Lenton, 2008a; Delrio \& Lenton, 2008), estableciendo modos de autoridad y legitimación derivados de la máquina de guerra (Deleuze \& Guattari, 1988) desplegada por el Estado en pro de su propia consolidación (Figura 3).

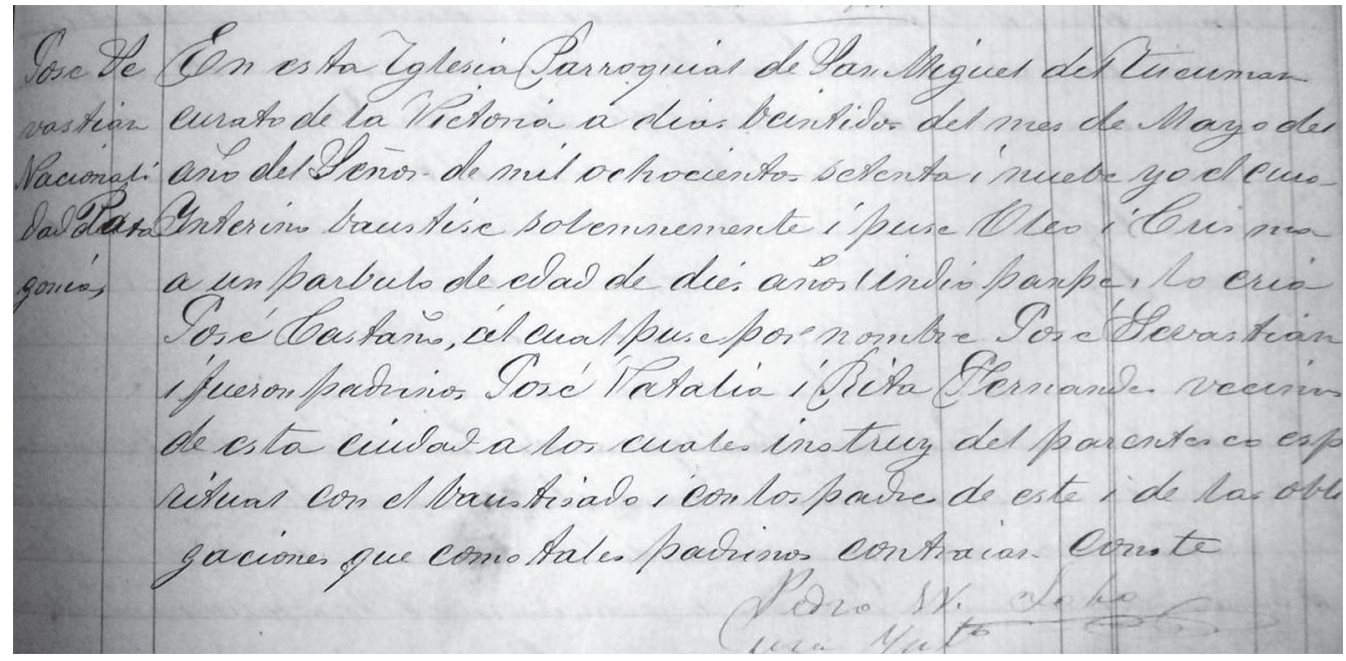

Figura 3

\section{Acta bautismal, asentada en una de las principales Parroquias} de la ciudad de San Miguel deTucumán, semejante a muchas otras, que da cuenta de la sustracción de niños de la frontera pampeano-patagónica y su envío a familias de la elite norteña, donde perdían su nombre y la información sobre su origen familiar, que era reemplazada por los datos de los apropiadores - que no llegan a constituirse en adoptantes. Textualmente se lee:

En esta Iglesia Parroquial de San Miguel del Tucuman curato de la Victoria a días veintidos del mes de Mayo del año del Señor de mil ochocientos setenta i nueve, yo el cura Interino bautizé solemnemente i puse Oleo i Crisma a un parvulo de edad de dies años (indio pampa). Lo cria José Castaño, al cual puse por nombre José Sevastian i fueron padrinos JoséVatalia i Rita Hernandes vecinos de esta ciudad a 
los cuales instruy del parentesco espiritual con el bautisdo i con los padres de este i de las obligaciones que como tales padrinos contraian. Conste... (firma).Y al margen, la nueva filiación del niño: José Sevastian - Nacionalidad: Patagonia.

Este es un caso excepcional entre los cientos de actas bautismales semejantes, dispersas por las parroquias tucumanas y salteñas, ya que se trata de un niño de bastante edad, en relación a la mayoría de los apropiados, que suelen tener entre 2 y 6 años. La fecha de su bautismo corresponde a la época de mayor impacto militar en la frontera pampeano-patagónica, aunque su filiación como "nacionalidad Patagonia" es índice de la endeblez, aun en 1879, del dominio estatal sobre dicho espacio.

(Fuente: fotografía de Lic. Jorge Sosa)

\section{Decantaciones de la política indigenista argentina}

Sostuvimos en otro lugar (Lenton, 2005) que las variaciones en la representación pública y hegemónica en el discurso político argentino sobre indígenas no obedecen a variaciones en las características o en las condiciones de vida de éstos, sino en las agendas y debates de las elites políticas en relación con contextos que los exceden.

Entre estos contextos deben tenerse en cuenta, en primer lugar, las nociones de comunidad contenidas por distintos paradigmas ideológicos - catolicismo, evolucionismo, nacionalismo, desarrollismo etc., nociones que constantemente se fueron redefiniendo y llenando de atributos, según los cuales incluir o excluir de ella a los Pueblos Originarios.

Siguiendo estas variables de comunalización y sus operaciones de inclusión / exclusión, existen otros colectivos que atraviesan similares vicisitudes y que funcionan como categorías complementarias, especulares o alternativas según el contexto histórico, y que se hallan implícitamente presentes en todo discurso sobre indígenas: criollos / nativos / gauchos; inmigrantes / extranjeros; argentinos "tipo" / urbanos / blancos / de elite. En efecto, la construcción del sujeto de las políticas indigenistas, más allá de sus diferentes apelaciones - indio / indígena / aborigen / nativo / poblador autóctono - debe analizarse conjuntamente con la construcción discursiva de otras entidades. En este sentido, se verifica una estrecha relación entre la construcción del sujeto de referencia de estas políticas y la construcción discursiva de otros sujetos sociales - especialmente argentinos / gauchos / inmigrantes / colonos - así como de colectivos con diferentes niveles de inclusividad 
- argentinidad / civilización / barbarie / occidente / cristiandad / desarrollo (cfr. Briones, 1998b).

En la práctica, hay registros suficientes en toda época como para afirmar que lo que en Argentina se ha definido como "problema indígena" constituyó, desde mediados del siglo XIX, más que una política consensuada, una agenda de debates. Esta agenda ha puesto en relación inescindible la cuestión indígena con un amplio rango de preocupaciones biopolíticas.

El debate público sobre la "cuestión indígena” fue abundante mientras la "conquista” de sus territorios era todavía una tarea pendiente o en pleno curso. El interrogante sobre "qué se va a hacer con estas tribus de indios, que vienen a someterse" ${ }^{17}$ estaba contenido en un debate omnipresente sobre cuáles eran las categorías y procedimientos más acertados para conducir a la nación hacia su destino de civilización. En este marco, la categoría social “indígena” con sus diferentes matices funciona como polo de oposición a determinadas categorías o como fuente de ejemplificación de otras. Puesta en el medio de argumentaciones que daban forma a paradigmas que la exceden, la categoría "indios" constituye sin embargo y al mismo tiempo un tema de preocupación concreta, que se consolida finalmente como paradigma de la administración del Otro durante los años de la llamada Organización Nacional.

Existe incluso una tensión entre, por ejemplo, los movimientos ideológicos y sociales que brindaron nuevos significados a la "ciudadanía" reconocible para la generalidad de los argentinos y los atributos y valoraciones simultáneamente dirigidos al sujeto de la política indigenista. Contrariamente a lo esperado, modificaciones visibles en la representación de la ciudadanía (por ejemplo, la reforma electoral y la extensión de derechos políticos en 1912, que permitieron por primera vez la llegada a la Presidencia de un partido popular, la Unión Cívica Radical) no fueron simultáneamente acompañadas por modificaciones convergentes en la representación del lugar del individuo indígena vis à vis dicha ciudadanía. Esto no significa ignorar los cambios producidos en la última, sino afirmar la existencia de ritmos y aceleraciones diferentes en ambos campos, relacionados con la existencia de capas de significación más o menos espesas que obturan coyunturalmente la efectivización del cambio. Quiero decir con esto que sin renegar de nuestra hipótesis, que relaciona fuertemente la construcción discursiva del sujeto indígena con la construcción discursiva de la nacionalidad, me permito matizar dicha relación innegable, con la afirmación de que ambas construcciones no guardan relaciones necesarias de simultaneidad, sino que presentan acronicidades y aparentes contradicciones que merecen ser indagadas.

Alrededor de 1880 se produce la fundación de una primera política indigenista de carácter estatal-nacional, que se define por referencia a un sujeto colectivo a su 
vez construido como el polo de una relación - a menudo denunciada - de tutelaje, de oposición política o de "ciudadanía incompleta" (Hernández, 2003), en todo caso, marcada por la asignación de una alta cuota de pasividad. Este nacimiento se produce a partir de la consolidación de la matriz Territorio-Nación-Estado (Delrio, 2005), resultado de procesos históricos concretos que culminan ca. 1880, y efecto de la triangulación "territorialización / temporalización / identidad" que, como describe Alonso (1994), opera en la constitución de sentidos y sentimientos de pertenencia, inescindibles de una matriz discursiva específica.

No obstante, a lo largo de las décadas siguientes, se reconocen puntos temporales de inflexión que rompen periódicamente la aparente homogeneidad del discurso político acerca del llamado "problema indígena". La primera ruptura se produce cuando el proyecto de la llamada Generación del ' 80 establece tres objetivos en relación a las tierras conquistadas y pueblos vencidos: afirmar la soberanía argentina sobre el territorio anteriormente bajo dominio indígena; erradicar las formas de vida "retardatarias" o "no civilizadas"; y construir una nación homogénea y moderna. Este proyecto político diseña un sujeto indígena en el que se maximizan las marcas de la ajenidad, produciendo el extrañamiento de los puntos de comunalización que décadas de experiencia de frontera mestiza habían sedimentado, y proyectando sobre el indígena el anverso de las imágenes de civilización que la sociedad del Ochenta tiene de sí misma. Este momento de la ideología política, que equivocadamente es propuesto por el sentido común y por cierta historiografía como representativo de un Estado de cosas "anterior" a la emergencia de un pensamiento más complejo sobre la realidad política argentina, constituye en realidad - y en esto acordamos con Bengoa (1994) - una ruptura fundamental con el anterior orden liberal, subsidiario de la utopía de la libertad y la igualdad. La construcción del sujeto indígena que hegemoniza en la Argentina el discurso político entre 1880 y 1900 tiende a consolidar la desigualdad, a partir de la diferencia como legitimación de la política, por sobre la igualdad y la libertad inmanentes a la ciudadanía.

A pesar de las perspectivas ochentistas de rápido acabamiento de la diversidad, las décadas siguientes se enfrentaron a la constatación de la perdurabilidad de los pueblos indígenas, algunos de ellos establecidos en comunidades formadas, localizadas y/o legalizadas luego de la conquista militar de los territorios. Se empieza a ensayar entonces la idea de que éstas son parte de la realidad argentina. Esta doble constatación es leída en forma positiva o negativa contra el fondo de la euforia por la modernidad y el éxito argentino.

Esto conduce a la segunda ruptura, que se produce en las dos primeras décadas del siglo XX, cuando el higienismo ${ }^{18}$ y el reformismo liberal se conjugan para 
repensar una política indigenista que, más que excluir, expulsar y encerrar, comenzase a establecer formas de asegurar el tránsito de aquellos irredimibles hacia su extinción definitiva, o su asimilación en los niveles inferiores de la sociedad nacional. El "trabajo" se convierte en la herramienta para la última, mientras la medicina, la psiquiatría y la criminología se ocupan de la primera. El sujeto de la política indigenista se va consolidando al mismo tiempo como objeto de la indagación sociológica y/o de la exhibición museológica, insertando una variable que no termina de ser digerida por su conversión en parte de la clase trabajadora.

De esta manera, la mirada racializante se confunde con el discurso sobre las "clases", en una geopolítica que presenta como inescindibles la abundancia de población mestiza con la predominancia de "clases bajas", contrapuesta a la culminación del "crisol de razas" en una amplia "clase decente", epítome de la nacionalidad.

Esta forma de visualizar al sujeto de la política indigenista se mantiene prácticamente sin cambios durante el período de hegemonía de la Unión Cívica Radical (1916-1930). Sin embargo, el yrigoyenismo logra instalar un concepto - el de reparación histórica, ligado al de deuda - que perdurará en el tiempo, hasta hoy, como una nueva orientación del Estado en relación con ese sujeto. Lo cierto es que hasta la década de 1920 no hubo en la legislación nacional intentos de sistematización de la política indigenista. ${ }^{19}$ Con las presidencias de Yrigoyen y M. T. de Alvear se multiplican las comisiones parlamentarias y los proyectos, sin que éstas se alejen de los rumbos tradicionales del paternalismo y el control social.

La llamada "década infame", ${ }^{20}$ paradójicamente, resulta ser uno de los períodos más ricos en el debate político en cuanto a la búsqueda y puesta a prueba de nuevas definiciones de políticas y sujetos, acuciadas por la crisis política mundial, mientras las iniciativas concretas en política indigenista se reducen a la mínima expresión. Los debates continúan las líneas asentadas en décadas anteriores, pero cruzadas por la cuestión racial (Lenton, 2001). Se tiende a leer las estrategias biopolíticas en términos de eugenesia, y a ello se sobreimprime la crisis de la ciudadanía en términos de representación política. Mientras tanto, el registro parlamentario da cuenta, a través de la denuncia - que sitúa al Poder Legislativo en un rol más cercano al de ciudadanía indignada que al de diseñador de la política - de acciones gubernamentales que vuelven a intentar la desaparición física de los pueblos indígenas a través de los desalojos masivos (Briones \& Lenton, 1997).

A partir de 1946 se refunda el Estado sobre el sedimento de las discusiones de los '30 y los '40. Durante el gobierno de Perón se inicia una política algo más orgánica de entrega y confirmación de títulos de propiedad, conjuntamente con los beneficios derivados de las nuevas determinaciones de la política laboral, que 
interpelan a los indígenas en tanto clase trabajadora / Pueblo / "descamisados" (Lenton, 2008c: 20 y ss.) etc. También se inician a partir de 1947 las primeras formas, muy limitadas, de incorporación política de ciertos dirigentes indígenas. Sin embargo, el énfasis de la política estatal estuvo puesto en los derechos laborales de los indígenas en tanto "pueblo trabajador" y en la recuperación de sus tierras bajo el paraguas de la lucha contra el latifundio, sin que se diera lugar a reivindicaciones específicamente étnicas (Figura 4). El peronismo, pese a una primera "presentación en sociedad" como movimiento de masas tendiente a la reivindicación de sujetos y a la implementación de políticas que invirtieran las razones de la dependencia y la injusticia, representó una combinación mucho más compleja de continuidades y rupturas (cfr. Lazzari, 2004).

El llamado "Malón de la Paz", una controvertida manifestación de opinión de comunidades del noroeste argentino, vale como ilustración de la inclusión de la justicia para los Pueblos Originarios en la agenda de la justicia social, y a la vez, de la frustración de toda perspectiva de participación más radicalizada en tanto indígenas. ${ }^{21}$

La nueva racionalidad gubernamental instalada por el peronismo requirió la transformación de los sujetos de "caridad" de la beneficencia privada en sujetos de "protección" estatal. Sin embargo, en el campo de la política indigenista, y a pesar de que, por ejemplo, las iniciativas de creación de un Patronato Nacional de Indios databan de largas décadas, esa transformación no terminó de realizarse. En contraste con el éxito secularizador y estatizador acumulado en el terreno de menores, mujeres y presidiarios en tanto objetos de tutelaje, ${ }^{22}$ la Iglesia siguió administrando una buena proporción de misiones, escuelas especiales, internados y colonias indígenas. ${ }^{23}$

Aun así, el énfasis en la protección estatal - que proyecta por reflejo la idea de que la expoliación del indio es ante todo privada - como recurso éticamente innegable, iniciado por el justicialismo, perdura hasta el día de hoy, siendo mucho más frecuente hallar al Estado en roles de protector o inclusive de denunciante del infortunio indígena, que haciéndose cargo de su responsabilidad en el mismo (Delrio \& Lenton, 2008).

En determinado momento histórico, el sujeto de las políticas indigenistas comienza a ser construido como un agente que, a través de la demanda por derechos de diferentes niveles de inclusividad, puede incidir en la modificación de la misma legislación y/o discurso legal que lo toma como objeto de referencia. En otras palabras, muy lentamente se va generando el espacio para que surja la posibilidad del reconocimiento de la agencia indígena desde la agencia estatal. Esto es consecuencia de la recepción en el Estado tanto de las características de 


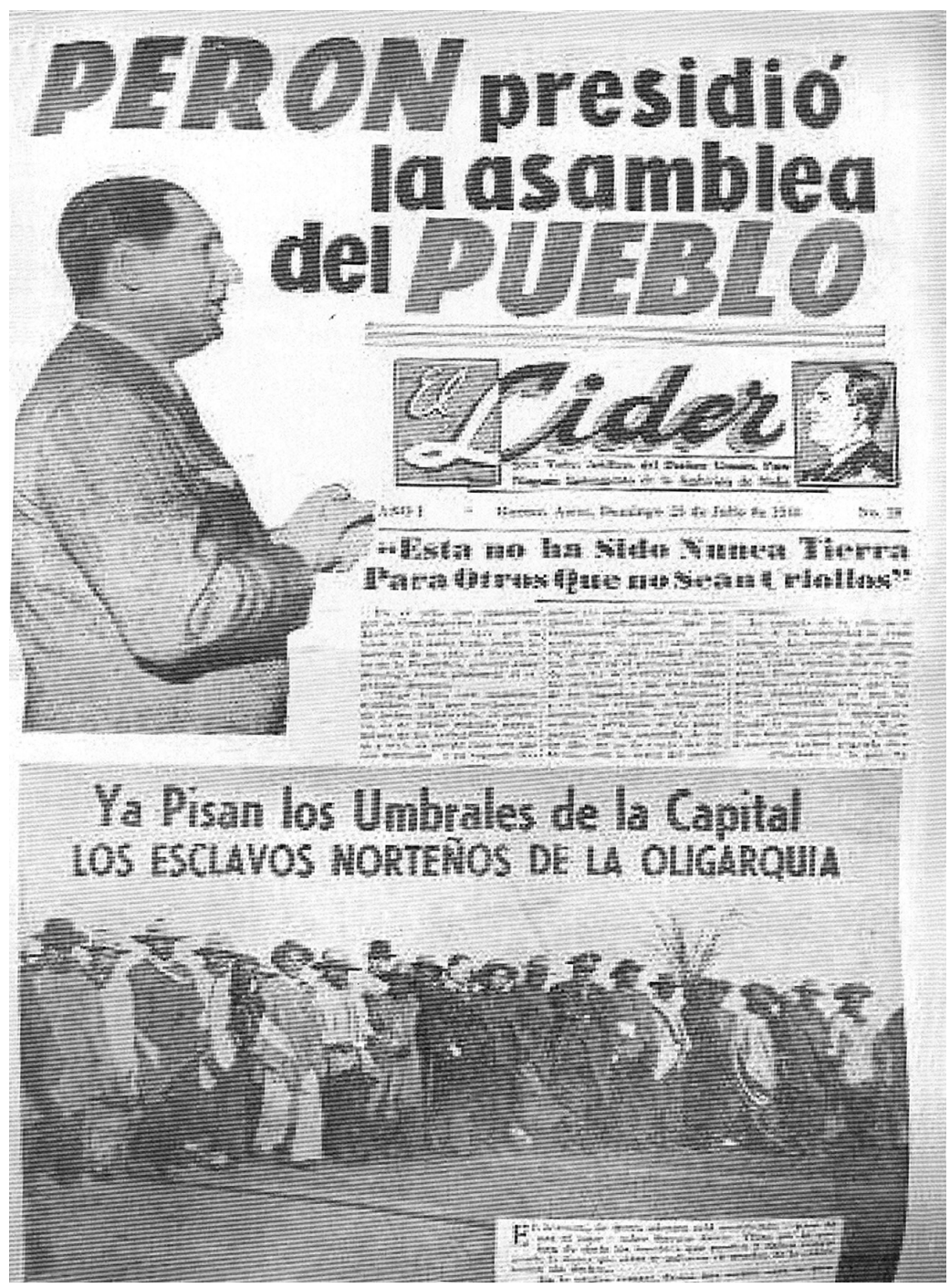

\section{Figura 4}

Primera plana del diario oficialista El Líder, 28/7/1946.

Fuente: Valko, 2007:313.

La portada ilustra la llegada y recepción de la famosa manifestación Kolla de 1946, y su imbricación en el discurso justicialista: son recibidos por el Presidente en tanto víctimas de la oligarquía. Pocos días después, el “desmadre” de las demandas kolla, que no se limitaban a la denuncia de las tierras usurpadas por el terrateniente en cuestión, terminó en represión, expulsión y silencio. 
la coyuntura local como de discursos de circulación internacional, cuyos hitos fundamentales son la lectura local de la Reunión de Pátzcuaro en 1940, cuyos ecos perduran en las fundamentaciones del Primer Censo Indígena Nacional en 1965; o el tratamiento oficial del Convenio 107 de la OIT sobre "protección e integración de las poblaciones indígenas, y de otras poblaciones tribuales y semitribuales en los países independientes", oficializado en nuestro país en 1959 a través de la ley 14.932.

Así, durante las presidencias desarrollistas de Frondizi e Illia resurge un discurso inspirado en gran parte en las líneas principales del indigenismo oficial mexicano, con énfasis en la aculturación y en la integración (incorporación) - ecos de la nueva alianza entre burocracia estatal y Academia - a través de la capacitación laboral y, en mucho menor medida, del otorgamiento de tierras aptas. En general, sin embargo, se evidenciaron las contradicciones entre la teoría desarrollista y la realidad de las relaciones políticas, que se patentizan en un discurso híbrido que potencia las referencias tecnocráticas al cambio y el desarrollo mientras reflota imágenes sociales afines a las del tiempo de la Organización Nacional.

Tras el golpe de Estado de 1966, la serie de gobiernos de facto iniciada por el general Onganía articula el modelo desarrollista - que continúa imponiendo sus enfoques a través de los técnicos de la CEPAL - con un nuevo énfasis en la llamada "gestión de comunidades", focalizando en el desarrollo de áreas de frontera, atomizando las políticas sociales y subordinándolas a la ascendiente Doctrina de Seguridad Nacional. La política indigenista se encuentra en la víspera de la emergencia - ya en los '1970 - de un estilo nuevo de movilización política y de nuevas formas de represión de la misma, que cruzará la cuestión indígena.

Entre 1973 y 1976, y vuelto el país a la legalidad institucional, el Ministerio de Bienestar Social continuó la tendencia de desarrollo de comunidades, que pretendió cristalizar en el proyecto de fundación de 504 Agrupaciones indígenas en "áreas de frontera". La "tercera presidencia peronista" propició al mismo tiempo políticas clientelares que impulsaron la creación de organizaciones políticas internas a las comunidades indígenas, cruzadas por líneas partidarias (Serbin, 1981; Carrasco, 1991).

El decenio anterior a la última dictadura tuvo gran incidencia en la historia de la militancia social y política de raíz indígena en Argentina. La efervescencia política y social de la época se hizo presente también en este campo, acompañando y dinamizando movimientos de reclamo por situaciones concretas de larga data.

Pese al reiterado y sostenido esfuerzo de control por parte del Estado - tanto durante el gobierno militar como durante el gobierno peronista - de todo lo que se relacionara con la ingeniería social, estos años vieron también el surgimiento 
de los primeras organizaciones indígenas de afirmación y reivindicación étnica pública, en un nivel suprafamiliar, supracomunitario y, en varios casos, reuniendo representaciones de diferentes Pueblos. Así, por ejemplo, en 1968 se fundó el Centro Indígena en Buenos Aires; en 1970 se formó la Confederación Indígena Neuquina; en 1973, la Federación Indígena del Chaco y la de Tucumán; y en 1975, la Asociación Indígena de la República Argentina y su retoño - en los confines de la década y ya en dictadura - el Centro Kolla, ambos en Buenos Aires. ${ }^{24}$ La vorágine política de esos años, si bien bañó por igual la vida social en todo el país, repercutió de manera disímil en las diferentes provincias, acorde tanto a las historias locales particulares de relacionamiento Estado-pueblos originarios, como a las diferentes construcciones locales de aboriginalidad (Figura 5).

Esta "nueva" movilización originaria fue muchas veces avalada por sectores de la Iglesia o el Estado. ${ }^{25} \mathrm{Si}$ bien comparto parcialmente la postura de varios autores ${ }^{26}$ acerca de la verificable manipulación de los liderazgos de estas organizaciones incipientes por parte de aquellas agencias, creo que el proceso de surgimiento y desarrollo de nuevas representaciones, así como la consolidación de una ideología étnico-política particular a principios de la década del '70, se relacionaba estrechamente con la agudización de los antagonismos socio-políticos en el país, y a la vez respondió a características particulares en el proceso de desarrollo interno de los Pueblos y comunidades, y a la coyuntura que atravesaba la cuestión indígena y las reivindicaciones étnicas en nivel mundial. ${ }^{27}$ De tal manera, el devenir de estas organizaciones y de sus liderazgos escapó en muchos casos y relativamente pronto al control de las agencias hegemónicas que pudieron haberlas impulsado. A pesar de indiferencias, vigilancias y represiones, la década del '70 vio surgir el protagonismo de una nueva - y perdurable - clase de agentividad indígena, que transformaría para siempre la política indigenista. La nueva generación de políticos originarios, formada en parte bajo los auspicios del indigenismo desarrollista estatal y de ciertos sectores progresistas de las iglesias y de la sociedad civil, exhibió características e inclinaciones que trascendieron las problemáticas estrictamente locales con las que el indigenismo tradicional asociaba la agentividad nativa. Particularmente en la Argentina, numerosas organizaciones indígenas locales comenzarían a agruparse y a conformar redes que apuntaron a trascender y a disputar por primera vez al Estado, la Iglesia y la Academia la autoridad de enunciación sobre la cuestión indígena en sus propios terrenos (Lenton, 2008b).

El ímpetu democratizador que acompañó el fin de la dictadura militar en 1983 y hasta iniciada la década del '90 implicó tanto la presión social para la reinstauración de derechos humanos ya aceptados, como la definición de nuevos sujetos de derecho (Briones et al., 2000). Comenzó así a instalarse la aceptación de una nueva 


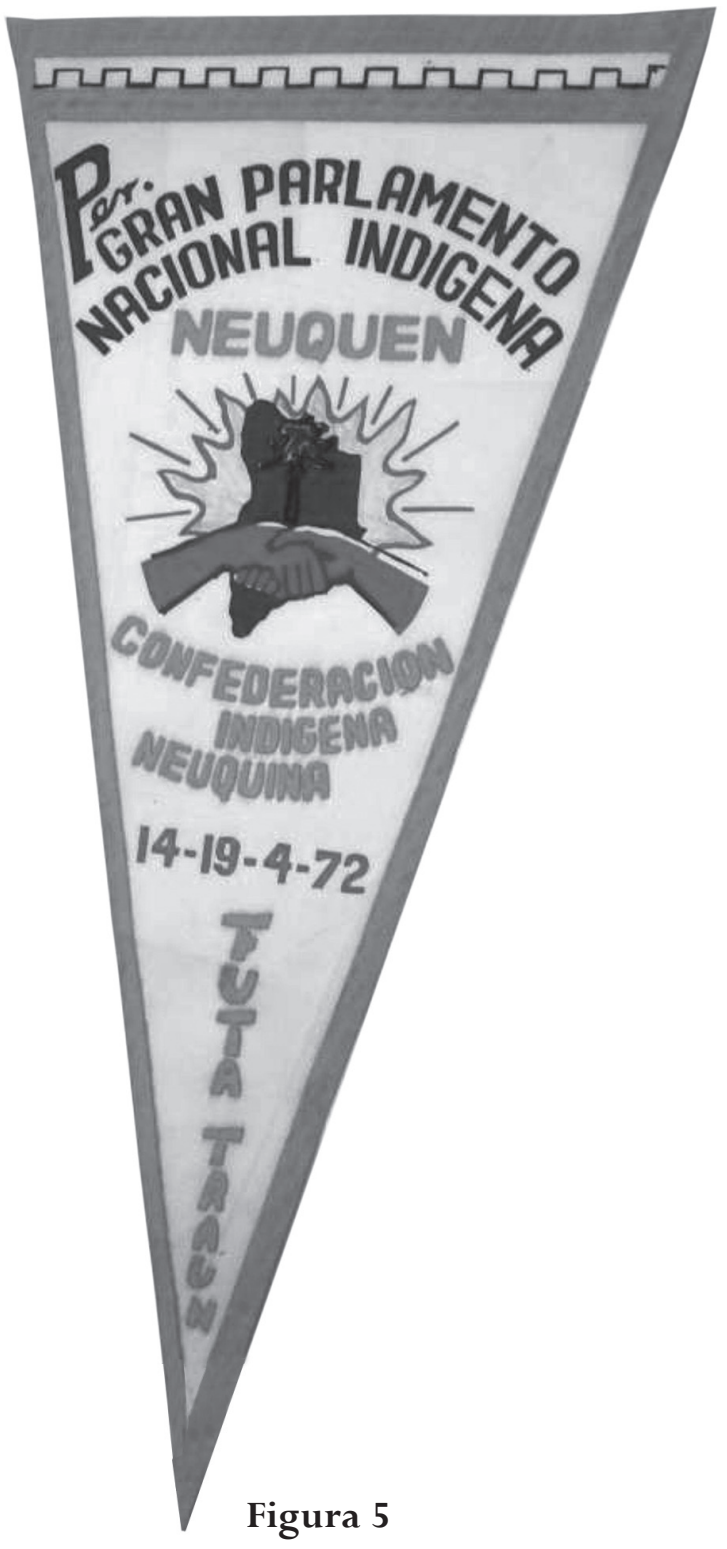

Emblema del Primer Parlamento Nacional de militantes indígenas, convocado en 1972 por la Confederación Indígena Neuquina recientemente creada. Adviértase la subordinación del nombre mapuche del encuentro a su denominación en castellano, y los préstamos del escudo oficial de la provincia - y cierta reminiscencia de la estética peronista - en el ícono que simboliza el encuentro. 
"generación” de derechos humanos, aplicables a aquellos sujetos colectivos cuya excepcionalidad se define por su preexistencia al Estado. En consonancia, entre 1984 y 1993 se sancionaron varias "leyes indígenas", es decir, cuerpos legales que buscaron definir de manera "integral” las relaciones entre indígenas y no indígenas. Se plegaron a este esfuerzo, que requirió no sólo la decisión sobre la política a seguir, sino también la definición del propio objeto de la ley, además del Congreso Nacional, las Legislaturas de varias provincias: Formosa, Salta, Chaco, Río Negro, Misiones, Chubut y Santa Fe (Briones et al., 2000:1).

Entre 1986 y 1998, en el mismo sentido, "veinte provincias se dieron nuevas constituciones, en un proceso que incluyó la reforma de la Constitución Nacional”. Algunas de las nuevas constituciones incluyen al menos un artículo referido al reconocimiento de derechos específicos a los Pueblos Originarios: las de las provincias de Salta, Jujuy, Río Negro, Formosa, Buenos Aires, Chaco, La Pampa, Chubut y Neuquén; y la Constitución Nacional. ${ }^{28}$

La vocación integral de esta explosión normativa, empero, se vio pronto desbordada por otro movimiento que llegaba a caballo del neoliberalismo y las corrientes disgregadoras que caracterizaron la década de 1990 y el cambio de siglo en la región. Me refiero a la tendencia neoasistencialista, particularizadora, privatizadora y antiestatal que inundó la política indígena, como otras políticas sociales, a partir de la década pasada (Lenton \& Lorenzetti, 2005). En este contexto, el Estado - nacional o provinciales - abordó la política indígena, ya canonizada, políticamente correcta y prácticamente privada de oposición, como un territorio simbólico a negociar con nuevos laderos interesados en la misma, especialmente ONGs y organismos multilaterales de crédito. ${ }^{29}$

La conversión de la política indigenista de Estado en política indigenista de aporte privado requirió la difusión y imposición previa de un paradigma multiculturalista que, si antes era propio del mundo anglosajón (Briones, 1998a; Sieder, 2004; Ulloa, 2005) y no incidía mayormente en el pensamiento social argentino, en los años de la flexibilización económica y social ingresó sutilmente hasta hacerse predominante en el ámbito privado y en algunas agencias estatales. ${ }^{30}$ Nos encontramos entonces ante un escenario de neoindigenismo (Briones \& Carrasco, 2004; Lenton \& Lorenzetti, 2005) cuyas derivaciones ameritan todavía investigación.

\section{Incorporación, exclusión, aboriginalidad y ciudadanía en la políti-} ca argentina: tensiones, rupturas y continuidades

A lo largo de los años, la matriz territorio-nación-Estado y la dicotomía civilización-barbarie persisten e inciden sobre las interpelaciones estatales al sujeto político indígena, más allá de sus variaciones según fueran cruzadas por las influ- 
encias matizadoras del higienismo, el yrigoyenismo, el revisionismo nacionalista, el justicialismo y el desarrollismo. Así, cada paradigma expresa la conceptualización de las relaciones entre la nación-como-Estado - autodefinida como no-étnica - y las sociedades indígenas etnicizadas y racializadas.

Como antropóloga interesada en construcciones discursivas de aboriginalidad, me interesa, como plantea Briones (1998b), identificar los sistemas de identidad y diferencia que subyacen en una historia nacional que ha excluido a los pueblos nativos de su narrativa.

Dicha exclusión de la narrativa histórica tiene un correlato en la historización que los científicos sociales solemos utilizar como punto de partida para nuestros análisis diacrónicos. En esta base, la exclusión tuvo entre otros efectos la de ocultar complejidades que consisten, por ejemplo, en que ciertos momentos de apertura del Estado argentino a la recepción de demandas de ciertos sectores no necesariamente coinciden con mayor sensibilidad a otras situaciones.

Por ejemplo, en el período de constitución de la nación-como-Estado - fines del siglo XIX - si bien convivían el paradigma evolucionista y el católico, la existencia de una frontera ideológicamente cargada modeló las acciones del Estado en función de la oposición "civilización y barbarie". Eso hizo que aun las acciones de la Iglesia, que siguiendo el paradigma católico hubiera incluido a los indígenas conversos la comunidad religiosa, se subordinaran a dicha oposición y funcionaran respecto de los "indios" en la forma de "misiones" subordinadas a la lógica de la conquista. Las acciones del Estado respecto de los indios se presentaron como excepcionales dentro del modelo de acciones de una nación civilizada, siguiendo la lógica de la máquina de guerra, y la variedad de acciones posibles y capitalizadas con anterioridad a 1879 se redujo a partir de 1880 a la política de administración de los prisioneros y vencidos en la guerra de fronteras. Sólo el fracaso de estas políticas y la emergencia del nacionalismo en relación al conflicto con Chile abrieron el abanico a iniciativas de localización de comunidades y, por ende, a la previsión de su existencia diferenciada como colectivos sociales sui generis.

Lo mismo puede decirse a propósito del reemplazo diacrónico de términos de referencia del sujeto de la política indigenista (indios, indígenas, aborígenes, pueblos originarios). La variabilidad de la terminología utilizada no se corresponde con una pluralidad de enfoques sobre la cuestión indígena, reconociéndose continuidades en el mandato paternalista de "civilizar" (adaptar, convertir), y rupturas que, por el contrario, no son inmediatamente reflejadas por reemplazos terminológicos. En todo caso, esta variabilidad en los conceptos tiene un paralelo con las oscilaciones permanentes a que se verá sometida a lo largo de todo el período analizado la agencia estatal a la que corresponda canalizar las políticas indigenistas. Me refiero a la 
falta de lineamientos coherentes por parte del Estado sobre qué área del aparato burocrático debería atender las cuestiones relacionadas con este sector, y de ahí el traslado de los organismos específicos de un Ministerio a otro, así como su creación, supresión, re creación o cambio de denominación.

Esta característica de la política indigenista nacional arraiga en la histórica falta de definición, tanto del grado de "alteridad" y de "argentinidad" contenido en la aboriginalidad - lo que compete a la agencia que los interpele - como del propio rol del Estado respecto de las demandas de los diferentes colectivos que lo componen. Es necesario recordar además que diferentes agencias estatales pueden trasuntar diferentes paradigmas. ${ }^{31}$ Sin embargo, existen coincidencias básicas que nos permiten describir una economía política de la diversidad (Briones, 2004:74) que la diferencian de la de otros estados de la región.

El proceso histórico de incorporación de los Pueblos Originarios al Estado nación, luego del sometimiento de los primeros, osciló entre dos tendencias simultáneas, cuya combinación variable incidió tanto en la formación de diferentes vías de comunalización, localización y radicación, como en la construcción de "trayectorias de aboriginalidad" (Ramos, 2005).

La primera de esas tendencias, verificable especialmente a nivel del discurso político, propugna la destribalización - qua invisibilización - de los pueblos originarios, a través de la implementación de políticas tendientes a su dispersión o a través del desconocimiento de su persistencia en tanto indígenas. Verificamos así largos períodos de evitación de la interpelación a los grupos indígenas en tal carácter, en pro de su disolución en colectivos compartidos con población no-indígena. Esta posición política es presentada por los creadores de discurso como prenda de voluntad integradora, de benevolencia o evitación del racismo (cfr. Quijada, 2000).

La segunda tendencia consiste en prácticas de espacialización y tribalización de la organización indígena (Briones \& Delrio, 2002), impulsadas por el mismo Estado que la disuelve en el discurso.

De esta manera, la especificidad de la aboriginalidad en la Argentina es deudora de la tensión entre un discurso alternativamente asimilacionista o segregador y las prácticas que redundaron en la construcción del indígena como una categoría específica de ciudadano, cuya incorporación subordinada en el colectivo nacional convive con una pretendida igualdad esencial ante las instituciones estatales.

A lo largo de la historia de la política indigenista argentina, se percibe una tensión entre la voluntad de extender los "beneficios de la civilización" a las poblaciones que no gozan de ellos por defectos de la práctica política y la conceptualización de esas mismas poblaciones como ajenas por su misma naturaleza a la posibilidad de gozar de esos beneficios plenamente. Esta tensión, que se manifiesta 
dramáticamente en los debates fundamentales sobre la cuestión en la década de 1880 - ocasiones en que el senador Mansilla define a los pueblos patagónicos como "refractarios a la civilización" (Diario de Sesiones del Senado de la Nación, sesión del 19/8/1885) - reaparecerá a través del tiempo, sobrevolando paradigmas y coyunturas, en las agencias de un Estado que aun hoy se autorrepresenta como administrador de un desarrollo inexorable. Más de un siglo después, entonces, los Pueblos Originarios siguen siendo difusamente definidos como una clase de "otros internos" cuya otredad es presentada, entre otras características, como cierta dificultad para compartir el "modo de vida civilizado", que es uno de los aspectos fundantes del proceso mismo de "comunalización" de la nación argentina. Pero al mismo tiempo, su carácter de "internos" demanda su homologación bajo ese modo de vida sobre el que la Nación pretende tener sus bases.

Este dilema identitario tiene un correlato con una segunda tensión entre dos ideas o figuras del Estado: la de guardián o tutor de estos "otros internos" no plenamente responsables de su destino; y la de proveedor - desde la primera tradición del Estado civilizador, educador y poblador, hasta la más reciente del Estado de Bienestar - de los ítems a los que de otro modo "ellos" no podrían, no sabrían, o quizás no querrían acceder. Por sobre esta tensión se percibe una noción que unifica a aquellas dos figuras del Estado, y es la de la "incapacidad esencial" de los indígenas para componer un derrotero similar, o equivalente, al de los ciudadanos "normalizados". Esta atribuida incapacidad, devenida en marca identificatoria de la aboriginalidad, es deducida en ciertos discursos como una consecuencia de la diversidad, pero también, en otros, se convierte en la causa que da origen a la desigualdad.

Se tiende a imponer así una interpretación hegemónica del problema como el de la insalvable diferencia entre un grupo - los aborígenes - cuya otredad se define por carencias, inmovilidades o retrasos y otro grupo - la nación - cuya característica definitoria es la posesión de "los beneficios del progreso / desarrollo" en razón de su capacidad evolutiva.

La esencialización de la carencia de desarrollo - o del retraso en el ritmo de su adquisición - como característica aborigen implica una etnicización (Briones, 1998a) que contempla la posibilidad de ser revertida con el paso del tiempo y la ayuda de los especialistas "bien-intencionados" - lo que los discursos decimonónicos definían como conversión bajo la mirada del filántropo, y el desarrollismo del siglo $\mathrm{XX}$ estableció como aculturación bajo la guía del técnico. Pero a la vez, la misma etnicización instala la desconfianza en la voluntad endógena del cambio. Un corolario de esta posición, que perdura en nuestros días, es la negación de la "autenticidad" de los individuos o grupos indígenas que reclamaran una participación mayor en el desarrollo que la que el Estado esté dispuesto a concederles. En esto, la sospecha será, entonces, que estas demandas sean inculcadas "desde afuera", o que quienes apelan al Estado en tanto aborígenes en realidad no lo son. 
El análisis de la política indigenista argentina nos permite verificar la centralidad del Estado nacional en la modelación de la misma, no obstante las variaciones locales o provinciales. ${ }^{32}$ La dinámica política de la segunda mitad del siglo XX determinó que la pertinencia o la validez de las políticas de población nacionales empezaran lentamente a problematizarse y discutirse en arenas internacionales. Con diferencias de ritmo sujetas al devenir de la política interna, las tendencias y los conceptos madurados en los foros "centrales" fueron ingresando en el discurso político local, renovando objetivos y frentes de acción. Esta nueva incidencia del discurso político generado en organismos internacionales, acompañado - aunque en forma despareja - por la transnacionalización del discurso y la agentividad indígena, aceleró el reconocimiento y la adopción de nuevas nociones de derecho que se visibilizarán a partir de los años '70.

Una consecuencia de lo apuntado es, a partir de los años ' 60 y hasta nuestros días, la adopción masiva y acrítica del concepto y la figura jurídica de comunidad como epítome de aboriginalidad. Además de negar variaciones internas a la categoría - que son resultado de diversas trayectorias de radicación y formación de comunidad en ambigua relación con el nivel de integración familiar, los procesos locales etc. (Briones, 2005b) - la equiparación entre el ser indígena y el ser parte de una comunidad indígena elude problematizar la densidad histórica del concepto. Impone además una modelización autoritaria de lo que la grupidad indígena debe ser, en consonancia, parafraseando a Delrio (2004), con lo que el Estado quiso que estas formaciones grupales fueran, ignorando las posibilidades de la aboriginalidad extra-comunitaria. ${ }^{33}$

A partir de la década de 1950, junto con la internacionalización de discursos y recursos políticos, se produce una diversificación de interlocutores y de emisores de discurso autorizado sobre la cuestión indígena que acaba con el señalado monopolio del Estado nacional (Briones, 2004). Efectivamente, la presencia cada vez más importante de organizaciones no-gubernamentales, especialmente las que derivan de foros internacionales, comienza a dejar su huella en el trabajo legislativo, anticipando un cambio en la gubernamentalidad que corre paralelo a la formación de nuevos "campos de negociación", en términos de Conklin y Graham (1995).

Esta nueva transnacionalización y diversificación de discursos y agencias políticas redundará en nuevos procesos y ritmos de definición de sujetos (Rose, 1999), potenciados por la emergencia de diferentes formas de agentividad indígena.

\section{La difícil construcción del sujeto de la política indigenista}

Como ya apuntamos, una parte fundamental de la política indigenista argentina consistió, paradójicamente, en la invisibilización ${ }^{34}$ de los Pueblos Originarios.

Los censos de población fueron herramientas clave en dicha invisibilización. De hecho, el análisis de las categorías censales empleadas demuestra que los censos 
han constituido más una expresión del deseo de ser de la nación-Estado que una herramienta para el conocimiento objetivo. ${ }^{35}$

Los primeros censos excluyeron explícitamente a la población indígena en tanto tal. En ocasión del $2^{\circ}$ Censo Nacional de Población realizado en 1897, los legisladores nacionales asumieron que la misma no había sido censada, aunque se ensayó una cifra de 90.000 individuos indígenas. ${ }^{36}$ No obstante, sabemos que algunos territorios incluyeron población indígena en sus recuentos. En Tierra del Fuego, por ejemplo, se nombraron "notables" para servir de empadronadores, quienes incluyeron concienzudamente a todos los indígenas que vivían en sus establecimientos, especificando nombre, edad, origen y oficio. Sin embargo, el afán censal no alcanzó a los indígenas no proletarizados, dado que aparentemente el objetivo del Censo era cuantificar ciudadanos o habitantes incorporados a la "civilización" o, al menos, al trabajo.

Para 1966, en ocasión del Primer Censo Indígena Nacional, una primera experiencia de relevamiento específico que se extendió varios años, coordinado por la academia antropológica y el Estado desarrollista (Lenton, 2004), el tratamiento de la categoría indígena reflejó una vez más los deseos estatales. En pleno auge de los objetivos de integración y aculturación, y siguiendo el paradigma de comunidad, el Censo eludió explícitamente a los individuos que no pertenecieran a comunidades indígenas rurales. También dejó de lado - inversamente a lo propuesto en 1897 - a las poblaciones localizadas en ingenios y obrajes del norte argentino, por considerar que estaban en vías de convertirse en obreros argentinos y, más aun, se evitó censar en las áreas consideradas folk, maximizando la distancia entre poblaciones indígenas y campesinas. De esta manera, quedaron fuera de ese conteo la mayor parte de los integrantes de Pueblos Originarios. A esto se agrega que por diversas razones el relevamiento proyectado no se concluyó y, más aun, no se terminó de procesar la información, brindando una cifra excesivamente subestimada de la población indígena, que sin embargo fue incorporada acríticamente por el Estado y gran parte de la "sociedad civil" como "la" cantidad absoluta de indígenas-argentinos, hasta la realización del Censo Nacional de Población en 2001 (Lenton, 2004).

Este último Censo, a diferencia de los anteriores, incluyó la determinación de la identidad originaria, respetando la autoidentificación individual, si bien limitada a ciertos Pueblos reconocidos por el Estado, ${ }^{37}$ y con dificultades varias en su realización. No obstante, refleja la nueva voluntad estatal de registrar la "diversidad", aun cuando dicho reconocimiento se subsume luego en cuadros de corte multiculturalista, que no implica necesariamente la generación de nuevas pautas de convivencia, y está lejos de una política intercultural.

Más efectivas en la creación de nuevas visibilidades han sido las reformas constitucionales, comenzando por la nueva Constitución Nacional en 1994, que adopta 
elementos sancionados en Foros Internacionales, como el Convenio 169 de la OIT, filtrados y adaptados por una intelectualidad indígena que no sólo fue artífice de un lobby sistemático y eficaz, sino que demostró estar más aggiornada en el estado del arte de la normativa internacional sobre Pueblos Originarios que los convencionales reunidos al efecto.

La reforma constitucional de 1994, en efecto, instaló principios que resultaron luego irrenunciables y que fueron paulatinamente adoptados por varias reformas constitucionales provinciales, a pesar de fuertes resistencias, principalmente, el reconocimiento de la preexistencia de los Pueblos Originarios al Estado-nación argentino y de las identificaciones que derivan de ello ${ }^{38}$, y el establecimiento de su derecho a la consulta previa cuando se afecten intereses que competen a sus territorios. ${ }^{39}$ El primer reconocimiento resulta de difícil digestión, tal como lo expresara el Dr. Manuel Moreira en esta misma reunión, dado que para el Derecho consolidado aparece como contradicción ontológica el pertenecer a una entidad preexistente al Estado argentino y, a la vez, ser un ciudadano argentino. El segundo reconocimiento mencionado, el que implica su derecho comunitario a decidir sobre su tierra y sus recursos, es violado y/o amenguado a diario, dado que, por un lado, entraña una radical oposición a intereses económicos que presionan con éxito sobre políticos y jueces, pero, más aun, porque implica una disonancia importante con el sentido común de los mismos políticos y jueces, que han sido formados para gobernar o dictaminar en un país sin indios.

Tal vez es por eso que la Ley 23302 "de política indígena y apoyo a las comunidades aborígenes” sancionada en 1985 sigue aún regulando - virtualmente - la política indigenista nacional a través de su órgano de aplicación, el Instituto Nacional de Asuntos Indígenas (INAI), a pesar de haber sido superada largamente en sus conceptos por la reforma constitucional y la adopción del Convenio 169 de la OIT. Esto implica la persistencia de paradigmas de subordinación por sobre la participación, y de un enfoque integracionista por sobre la declamada interculturalidad. Y, obviamente, nada de consulta previa sobre territorios, recursos ni ejercicio de la cultura, dado que, en el marco de esta ley y de los paradigmas que la inspiraron, el Estado es el dador de beneficios en una relación unidireccional.

La aplicación de los nuevos derechos reconocidos por las constituciones reformadas resulta limitada por lo general a espacios no vinculantes, en gran medida folklorizados y tamizados por criterios estatales de representación política válida. En cierta medida entonces, la política indigenista argentina se muestra en la actualidad, como hace un siglo, errática e inorgánica, a despecho de ciertas continuidades - la negación, la invisibilización, el paternalismo - que, a pesar de negarse en la superficie, siguen minando nuestras condiciones de convivencia. 


\section{Notas}

*Este artículo reproduce mi participación en el Seminário Internacional A Questão Indígena e o Estado: Os Casos do México, Argentina e Brasil, realizado el 20 de noviembre de 2008 en la Universidade de Brasília (UnB). El mismo capitaliza resultados de mi investigación doctoral sobre la política indigenista argentina desde 1880, y de mi investigación actual auspiciada por el CONICET, sobre las organizaciones de militancia de Pueblos Originarios. Agradezco a las Dras. Alcida Ramos y Claudia Briones por su oportuno estímulo.

1. "Indio" es la más rechazada de las apelaciones, tanto por ser la más antigua, directamente impuesta por el desorientado conquistador español, como por haber pasado al discurso cotidiano como insulto. Sin embargo, también ella fue reivindicada por las organizaciones de militancia indígena, bajo el lema "Si como indios nos sometieron, como indios nos liberaremos" (Primer Congreso del CISA en Ollantaytambo, 1980). Y al día de hoy, es reflotada por aquellos que desean enlazar el "indigenismo" romántico con supuestas inclinaciones o vocaciones pro-indígenas de los próceres indiscutidos de la argentinidad, epitomizadas en el "Nuestros paisanos los indios" de José de San Martín.

2. Una definición amplia del indigenismo intelectual y/o político requiere tres elementos: la denuncia de "la opresión del indio", la búsqueda de políticas de superación de ell a través de su "integración al conjunto de la sociedad", y la manifestación del carácter mestizo del continente (Bengoa, 1994). Tal vez es este último factor el que determinó la palidez de la tendencia en Argentina, comparativamente con las producciones coetáneas de otros centros ideológicos americanos (Lenton, 2005, 2008 b). Ver, por ejemplo, Arvelo-Giménez, 1990; Beigel, 2003; Ramos, 1990; Bartolomé, 1996.

3. Entre la abundante bibliografía sobre el empleo de mano de obra indígena - antes y después de las "campañas militares contra los indios" - en ingenios azucareros y obrajes madereros, así como en apertura de caminos, canales y vías de ferrocarril, véase Iñigo Carrera, 1984, 1988; Lois, 1998; Conti et al., 1988; Lenton, 2001; Mases, 2002; Cordeu \& Siffredi, 1971. De hecho, las campañas militares roquistas y posteriores se realizaron habiendo ya experiencia previa de utilización masiva de mano de obra indígena, desde mediados del siglo XIX, en las industrias obrajera y maderera, y este factor fue considerado por la oposición que negaba la "necesidad" de avanzar militarmente sobre el Chaco, dada la "mansedumbre" y la disposición para el trabajo de los pueblos que lo habitaban (Gordillo, 1995; Trinchero, 2000; Lois \& Troncoso, 1998; Rosenzvaig, 1986; Lenton, 2005).

4. En particular la industria azucarera, primera agroindustria nacional, ofició desde fines del siglo XIX como organizadora del mercado de trabajo regional en todo el NOA (Vázquez Labá. 2004:17), con formas de reclutamiento y control de la clase trabajadora diferenciadas por etnia (Aparicio \& Panaia, 2000; Mases, 2002; Rutledge 1987:229, cit. en Vázquez Labá, 2004:17), coadyuvada por un sistema político-legal específico (Teruel, 1991; Rosenzvaig, 1986). 
5. Esta denominación, que es objeto de un viejo debate historiográfico que no es posible detallar aquí, comprende las Presidencias positivistas de Nicolás Avellaneda (1874-1880), Julio A. Roca (1880-1886), Miguel Juarez Celman - Carlos Pellegrini (1886-1892) y, según algunas visiones, las que siguieron hasta la finalización de la segunda Presidencia de Roca y el ascenso del reformismo liberal en 1904.

6. Ya en la década de 1880, antes de la expedición al Chaco del ministro Victorica, se debatió en el mundo político y académico la posibilidad de "civilizar" a los indígenas locales a partir de su incorporación al trabajo, a cambio de sus ventajas adaptativas frente a la inmigración, por su resistencia al medio y, especialmente, por la posibilidad de una mayor explotación laboral. Este debate se prolongó por décadas. Ya en 1917, el diputado socialista Juan B. Justo promovía una interpelación al Poder Ejecutivo confirmando que los empresarios azucareros estaban especialmente interesados en que los trabajadores fueran indios chaqueños, y relacionaba la formación de la mano de obra indígena con el proceso de expropiación de sus tierras (Diario de Sesiones de la Cámara de Diputados de la Nación, sesión del 31 /7/1917). Ver también Lenton (2001).

7. Ver especialmente Pimenta (2003) sobre la "conquista do deserto occidental" en la incorporación del Acre.

8. En el discurso político-militar de fines del siglo XIX, el desierto suele ocupar metonímicamente el lugar del propio indígena / bárbaro / salvaje: el "[...] inmenso desierto, guarida reciente de las belicosas tribus que lo habitaban y cuyo recuerdo inspira todavía pavor...” (Julio A. Roca ante la Asamblea Legislativa, 8/5/1881). Pablo Wright (2003) desarrolla la "narrativa del desierto" como elemento de la ideología oficial sobre el indígena chaqueño, en las primeras décadas del siglo XX.

9. Tal vez, dentro de unos años, estemos en condiciones de evaluar si los nuevos frentes económicos de la soja y de la minería de gran escala, con su desplazamiento de fronteras productivas, su aplicación de tecnologías ad hoc y su terrible impacto sobre territorios y pueblos, constituyen una nueva fase, tal vez definitoria, de aquel proyecto económico.

10. Ver por ej. las repercusiones de una investigación muestral reciente sobre el ADN mitocondrial de los argentinos (Corach, Sala \& Marino, 2005): http://www.pagina12.com.ar/diario/ciencia/19-54853-2005-08-10.html; y http://74.125.47.132/ search?q= cache:OK3Co2H7nioJ:www.clarin.com/diario/2005/01/16/sociedad.

11. Estudios antropológicos más o menos recientes, como los de Diego Escolar (2003), relevan la presencia y vitalidad del Pueblo Huarpe en el oeste argentino, a pesar de que desde hace muchas décadas se lo mencionaba entre los pueblos extinguidos. De la misma manera, el Censo Nacional de Población realizado en 2001 sorprendió con la constatación de la existencia y autoidentificación de Tonocotés, Comechingones y Onas; en el caso de estos últimos, con presencia mayoritaria relativa en la europea Ciudad de Buenos Aires, más que en su Tierra del Fuego ancestral. 
12. Para más detalles en el caso argentino, ver Lenton (2005).

13. Entendida como la historia de la "objetivización" de conceptos que hemos dado en asumir como "objetivos" (Dussel, 2003:3; Foucault, 1991:86).

14. En 1884, aún en plena operación militar, el Presidente Julio A. Roca anunciaba a la Asamblea Legislativa: "No cruza un solo indio por las extensas pampas donde tenían sus asientos numerosas tribus..." (Diario de Sesiones del Congreso Nacional, sesión del 6/5/1884). La llamada Campaña del Desierto iniciada por el presidente Avellaneda en 1878 y culminada por Roca - probablemente la más famosa de las políticas indigenistas argentinas - finaliza oficialmente en 1885, con la rendición de Sayhueque. Por su parte, la Campaña del Desierto del Norte, o Campaña militar al Chaco, tiene fecha oficial de finalización, rubricada por el presidente Hipólito Yrigoyen, en 1917. Si bien estas campañas militares sobre los territorios indios no fueron ni las primeras ni las últimas en nuestra historia republicana - debiendo mencionarse las campañas de Martín Rodríguez, J.M. de Rosas y otros con anterioridad, e infinidad de incursiones de policía militar, a posteriori - diversos factores contribuyeron a su difusión y permanencia como epítome del avance del estado - y de la nación genómica y culturalmente europea - sobre la tierra y los cuerpos originarios.

15. El monismo jurídico incidió no sólo en la morosidad con que aun hoy la Argentina se dispone a considerar la validez de los derechos colectivos, sino que determinó, a partir de los años de la llamada Organización Nacional, la negación del derecho de gentes anteriormente vigente, y el ocultamiento de un extenso bagaje de tratados con caciques, tribus, naciones y otras entidades válidas, que se habían producido hasta fechas tan tardías como 1878.

16. El artículo $11^{\circ}$ de la "Convención para la Prevención y la Sanción del Delito de Genocidio", aprobada por la ONU el 9 de abril de 1948, establece que "se entiende por genocidio cualquiera de los actos mencionados a continuación, perpetrados con la intención de destruir, total o parcialmente, a un grupo nacional, étnico, racial o religioso, como tal: a) Matanza de miembros del grupo; b) Lesión grave a la integridad física o mental de los miembros del grupo; c) Sometimiento intencional del grupo a condiciones de existencia que hayan de acarrear su destrucción física, total o parcial; d) Medidas des $\neg$ tinadas a impedir nacimientos en el seno del grupo; e) Traslado por la fuerza de niños del grupo a otro grupo". Todos los ítems mencionados se verificaron durante las campañas militares contra los indígenas, y se proyectan hasta años relativamente recientes.

17. Ministro Francisco Ortiz, durante su interpelación por el Congreso Nacional, sesión del 24/8/1885.

18. El higienismo constituyó un programa de profilaxis social frente a las consecuencias no deseadas del modelo económico-social impuesto, privilegiando la prevención mediante las “obras de salubridad" tendientes a la construcción de un medio ambiente urbano saludable (Recalde, 1999). Este carácter de asociación entre la antigua etiología con la nueva percepción del ambiente natural y social iniciada en la década de 1870 implicó también la construcción de 
una nueva epidemiología que propugnaba la integración a la cultura y el progreso sanitarios de una base social más amplia que las elites.

19. La excepción, ya en los años '20, fueron varios proyectos de regulación del trabajo de los indígenas - epitomizado en el trabajo en obrajes madereros e ingenios azucareros - impulsados por el radicalismo, y otras tantas iniciativas de prohibición del consumo de alcohol en áreas de predominancia aborigen, impulsadas por el socialismo (Lenton, 2005).

20. Se llama así al periodo que va desde el primer golpe de Estado cívico-militar, en 1930, hasta la reinstauración del gobierno constitucional, en 1946.

21. El tema ha sido desarrollado y discutido especialmente en Kindgard (2004), Lenton (2008c), Belli; Slavutsky \& Rueda (2007) y Valko (2007).

22. Ver especialmente Caimari (2004); Villalta (2001).

23. Esta aparente paradoja se prolonga en el tiempo. Hasta 1958, 1os Directores de la Comisión Honoraria de Reducciones de Indios solían ser reconocidos científicos o expertos. En 1958 el presidente Frondizi deja de lado su impulso desarrollista científico para nombrar al frente de la Dirección Nacional de Asuntos Indígenas al sacerdote Emilio Martínez. Ya en los años '70, la persistencia de la relación entre la cuestión indígena y las instituciones Iglesia y Ejército dejará su impronta en las primeras organizaciones de militancia originaria.

24. Estas organizaciones de segundo nivel fueron precedidas en muchos casos por la realización de grandes reuniones y encuentros que contribuyeron a consolidarlas y/o institucionalizarlas. Entre ellos, el Segundo Parlamento Indígena del Neuquén, en 1971; el Primer Parlamento Indígena del Chaco, en 1972, y poco después en ese mismo año, el Primer Parlamento Nacional Indígena "Futa Traun” de Neuquén; en 1973, el Primer Parlamento Indígena de los Valles Calchaquíes, y en ese mismo año, el Segundo Parlamento Indígena Nacional, en la Capital Federal. Este encuentro, explícitamente presentado como ampliación y continuación del Futa Traun de 1972, fue bautizado “Segundo Parlamento Nacional 'Eva Perón””, y si por una parte recibió el aporte renovador de gran número de representantes de las provincias norteñas - especialmente Chaco y Formosa - también resultó obvia su subordinación a la agenda política del gobierno camporista.

25. Efectivamente, no puede dejarse de lado la influencia de ciertas corrientes internas de la iglesia local - siendo la iglesia neuquina el caso paradigmático - así como la confluencia de objetivos con algunas organizaciones del campo social y sindical, como las Ligas Agrarias del Nordeste y otras entidades, como la FUCSA (Federación Unida Campesina de Salta). Probablemente, esta vinculación de los movimientos indígenas setentistas con algunos proyectos populares de transformación nivel nacional fue el factor de mayor peso que condujo a la posterior represión del movimiento indígena en su conjunto. A partir del golpe de estado de 1976, numerosas organizaciones fueron desmanteladas y/o sus miembros perseguidos; algunos fueron desaparecidos, otros se exiliaron, otros abandonaron la militancia política y otros la continuaron mediante estrategias de supervivencia variadas, que son objeto de otra investigación. 
26. Ver Falaschi, C. O.; Sánchez, F. \& Szulc, Andrea, 2005; Briones \& Díaz, 1997; Radovich, 1992; Serbín, 1981.

27. Ver Bartolomé, 2002.

28. Briones et al., 2000:1. Ver también Carrasco et al., 2000. Resulta de interés indagar también por qué, a pesar de disponer de los mismos recursos ideológicos, las provincias de La Rioja, San Luis, Córdoba, Catamarca, San Juan, Tierra del Fuego, Corrientes, Santiago del Estero y Santa Cruz, y la Ciudad Autónoma de Buenos Aires decidieron no incluir referencia alguna a los Pueblos Originarios en sus reformas constitucionales, pese a que varias de ellas cuentan con comunidades reconocidas por sus propias agencias estatales.

Neuquén es un caso especial porque los constituyentes de 1993 se limitaron a copiar el artículo incluido en la Constitución provincial de 1957, cuando era pionero en el reconocimiento de la diversidad, a pesar de que los años transcurridos habían afectado gravemente su valor de novedad, especialmente ante sujetos que ya no se veían interpelados por ella. Sin embargo, las provincias de Neuquén y Tucumán atravesaron nuevas reformas constitucionales en 2006, que implicaron la "puesta al día” en el reconocimiento de derechos específicos.

29. Entre estos últimos, en Argentina son paradigmáticos desde hace 10 años los diseños de política asistencialista en general, e indigenista en particular, realizados e impuestos por el Banco Mundial, el BID, la Agencia de Cooperación Iberoamericana y, más discretamente, la Cooperación Económica de la Unión Europea, Japan Internacional Cooperation Agency, Fondo Coreano de Inversión para la Reducción de la Pobreza, AVINA y otros. Soy consciente de la sobresimplificación que implica el carácter del asistencialismo / neoasistencialismo y el indigenismo / neoindigenismo que les atribuyo aquí, en honor a la brevedad. Ver Castro, 2008; Casaburi \& Tussie, 2000; Carrasco, Sterpin \& Weinberg, 2006; Mastrangelo, 2005; Raggio, 2004; Briones, 2005; Rose, 1997.

30. Por ejemplo, ver http: / / www.inadi.gov.ar/inadiweb/index.php

31. En la Argentina, al órgano específico de aplicación de la Ley de Política Indígena, el Instituto Nacional de Asuntos Indígenas (INAI), dependiente del Ministerio de Desarrollo Social, se le suma el Instituto Nacional contra la Discriminación, la Xenofobia y el Racismo (INADI), dependiente del Ministerio de Justicia, Seguridad y DD.HH., y oficinas especializadas en diferentes Ministerios, como el Programa Médicos Comunitarios, la Dirección Nacional de Política Socioeducativa etc., todas ellas agencias estatales vigentes con rango federal y con diversa interpretación de la política indigenista.

32. Para profundizar el análisis de la aboriginalidad en relación a los contextos provinciales, ver Briones (comp.), 2005.

33. Por otra parte, debe apuntarse que esta noción, introducida en nuestro medio político en 1957 (Lenton, 2005), coincidiendo con el momento en que el mismo concepto deviene "gubernamental” como resultado de su aplicación como término técnico por la Sociología Estadounidense (Rose, 1999:175), denota utopías y perspectivas críticas de la sociedad oc- 
cidental capitalista, que asimilan esta noción, supuestamente técnica y aplicable a "poblaciones precapitalistas”, a experiencias de resistencia al acoso de la modernidad surgidas en el seno de los países centrales.

34. Pese a que la "invisibilización” producida o intentada por el Estado ya se ha convertido en un lugar común en la reflexión sobre Pueblos Originarios, me interesa llamar la atención sobre el etnocentrismo contenido en este concepto, si no se reconoce que dicha invisibilización no produce los mismos efectos en el seno de dichos Pueblos. La pregunta es, Invisibles, para quién? Sin embargo, aunque no es éste el lugar apropiado para desarrollar extensamente este punto, quisiera adelantar que la invisibilización producida desde el lado hegemónico se correspondió en el seno de la sociedad originaria con cierto proceso que podríamos llamar -a falta por ahora de un término más apropiado - de desensibilización, que aletargó la resistencia posible, hasta la emergencia a fines del siglo XX de nuevas prácticas de autorrepresentación originaria.

35. Ver también Otero (2004).

36. Diario de Sesiones del Senado de la Nación, sesión del 7/9/1897.

37. En un principio, la planilla Censal y la Encuesta Complementaria sobre Pueblos Indígenas que le siguió consideraban la posibilidad de autoidentificación a 18 Pueblos, reconocidos por el Estado. Implícitamente, el mismo Estado estaría negando otras posibles identidades. Sin embargo, la abrumadora marcación de la categoría prevista "Otros" obligó al Instituto Nacional de Estadística y Censos a recapacitar sobre algunas categorías e incluirlas durante el procesamiento de los datos. Por ejemplo, en la planilla original no se hallaba prevista la identidad Aymara, siendo conocida la gran cantidad de argentinos pertenecientes a este Pueblo. La omisión no es inocente, y responde a la persistencia del nacionalismo como parámetro de evaluación de la pertenencia originaria, que impone "autoctonías" a determinados pueblos considerados interiores a la frontera, y eternas extranjerías a quienes - como los Mapuche o los Aymara - ciertas corrientes pseudocientíficas consideran llegados “después”, sobre la espalda de inmigrantes no deseados (Lazzari \& Lenton, 2000). El nacionalismo deriva en xenofobia cuando niega a los descendientes de aquellos inmigrantes - en el caso de que sea la inmigración la única razón de la presencia interna de estos pueblos, tema de otra discusión la posibilidad de recrearse como argentinos y a la vez pertenecientes a un pueblo originario, argentinos-aymara, en este caso, reservando la identidad aymara sólo para los bolivianos... debiéndose suponer que los descendientes argentinos de bolivianos aymara, al nacer, pierden su etnicidad, o se convierten en argentinos "no-étnicos" porque no tienen el permiso para identificarse.

38. Las dificultades en la caracterización del sujeto censable, tanto como de la participación de los Pueblos Originarios en esta cuestión, garantizada en la Constitución Nacional, epitomizaron la relación entre Pueblos Originarios durante muchos meses, sucediéndose asambleas, tomas pacíficas del INAI, manifiestos, creación de mesas de diálogo e iniciativas 
persuasivas de variada clase (Lenton \& Lorenzetti, 2005:248 y ss.). Luego de su realización la protesta originaria amainó, y aunque el procesamiento de los datos censales distó mucho de ser el mejor posible, el ímpetu se había perdido, permitiéndose hoy la difusión de los resultados sin crítica.

39. Constitución de la Nación Argentina, 1994. Art. 75º, inciso 17: "Corresponde al Congreso [...] Reconocer la preexistencia étnica y cultural de los pueblos indígenas argentinos. Garantizar el respeto a su identidad y el derecho a una educación bilingüe e intercultural; reconocer la personería jurídica de sus comunidades, y la posesión y propiedad comunitarias de las tierras que tradicionalmente ocupan; y regular la entrega de otras aptas y suficientes para el desarrollo humano; ninguna de ellas será enajenable, transmisible, ni susceptible de gravámenes o embargos. Asegurar su participación en la gestión referida a sus recursos naturales y a los demás intereses que los afectan. Las provincias pueden ejercer concurrentemente estas atribuciones". 


\section{Referências bibliográfícas}

ALONSO, Ana María. 1994. "The Politics of Space, Time and Substance: State Formation, Nationalism, and Ethnicity". Annual Review of Anthropology, 23.

APARICIO, Susana \& PANAIA, Marta. 2000. "Los orígenes de los asalariados en el NOA”. In: M. Panaia M.; S. Aparicio \& C. Zurita (orgs.). Trabajo y población en el Noroeste argentino. Buenos Aires: Ed. La Colmena.

ARVELO-JIMÉNEZ, Nelly. 1990. "Indigenismo y debate sobre desarrollo amazonico: Reflexiones a partir de la experiencia venezolana”. Série Antropologia, 106, Brasília.

BARABAS, Alicia. 2000. "La construcción del indio como bárbaro: de la etnografía al indigenismo". Alteridades, 10(19):9-20, México.

BARTOLOMÉ, Miguel Alberto. 1996. "Pluralismo cultural y redefinición del Estado en México”. Série Antropologia, 210, Brasília.

. 2002. “Movimientos indios en América Latina: los nuevos procesos de construcción nacionalitaria”. Série Antropologia , 321, Brasília.

BEIGEL, Fernanda. 2003. El itinerario y la brújula. El vanguardismo estético-político de José Carlos Mariátegui. Buenos Aires: Ed. Biblos.

BELLI, Elena; SLAVUTSKY, Ricardo \& RUEDA, Pantaleón. 2007. Malón de la Paz "una historia, un camino". Buenos Aires: Instituto Interdisciplinario Tilcara, Ed. de la Facultad de Filosofía y Letras, Universidad de Buenos Aires.

BENGOA, José. 1994. "Los indígenas y el Estado Nacional en América Latina”. Anuario Indigenista, vol. XXXIII:13-40, Instituto Indigenista Interamericano, México D.F.

BRIONES, Claudia. 1995. "Hegemonía y construcción de la 'nación'. Algunos apuntes". Papeles de Trabajo, n. 4, Centro de Estudios Interdisciplinarios en Etnolingüística y Antropología Sociocultural, U.N.R. 
. 1998a. "La alteridad del 'Cuarto Mundo’. Una deconstrucción antropológica de la diferencia”. Buenos Aires: Ediciones del Sol.

. 1998b. “(Meta)cultura del Estado-Nación y estado de la (Meta)cultura”. Série Antropologia, 244, Brasília.

2004. "Construcciones de aboriginalidad en Argentina". Société Suisse des Américanistes / Schweizerische Amerikanisten-Gesellschaft. Bulletin, 68:73-90.

. 2005. "Formaciones de alteridad: contextos globales, procesos nacionales y provinciales". In: . (org.). Cartografías argentinas: políticas indígenas y formaciones provinciales de alteridad. Buenos Aires: Ed. Antropofagia. pp. 9-40.

(org.). 2005. Cartografías argentinas: políticas indígenas y formaciones provinciales de alteridad. Buenos Aires: Ed. Antropofagia. pp. 9-40.

\& CARRASCO, Morita. 2004. "La lucha por la tierra. (Neo)indigenismo estatal y producciones indígenas en Argentina” (1985-1999). In: E. Cruz \& R. Paoloni (orgs.) La propiedad de la tierra: Pasado y presente. Arqueología, historia y antropología sobre la problemática de la propiedad de la tierra en la Argentina. Anuario del CEIC 3/2003, Universidad Nacional de Jujuy. pp. 228-265.

; CARRASCO, Morita; ESCOLAR, Diego \& LENTON, Diana (GELIND). 2000. "El espíritu de la ley y la construcción jurídica del sujeto 'pueblos indígenas'”. VI Congreso Argentino de Antropología Social, Simposio Relaciones Etnicas e Identidad, Mar del Plata.

\& DÍAZ, Raúl. 2000. "La nacionalización/provincialización del 'desierto'. Procesos de fijación de fronteras y de constitución de 'otros internos' en el Neuquén”. Actas del V Congreso Argentino de Antropología Social, parte 3:44-57, La Plata.

\& DELRIO, Walter, 2002. "Patria sí, Colonias también. Estrategias diferenciales de radicación de indígenas en Pampa y Patagonia (1885-1900)”. In: Ana Teruel; Mónica Lacarrieu \& Omar Jerez (orgs.). Fronteras, Ciudades y Estados. Córdoba: Alción Editora. 
\& LENTON, Diana. 1997. "Debates parlamentarios y nación. La construcción discursiva de la inclusión / exclusión del indígena”. Actas de las III Jornadas de Lingüística Aborigen, pp. 303-318, Instituto de Lingüística, UBA, 20-23 de mayo, Buenos Aires.

CAIMARI, Lila. 2004. Apenas un delincuente. Crimen, castigo y cultura en la Argentina. 1880-1955. Buenos Aires: Siglo XXI ed.

CARRASCO, Morita. 1991. "Hegemonía y políticas indigenistas argentinas en el Chaco centro-occidental”. América Indígena, vol. LI, 1: 63-122, enero-marzo, Instituto Indigenista Interamericano, México.

; BRIONES, Claudia; LENTON, Diana \& SIFFREDI, Alejandra (GELIND). 2000. "La producción legislativa entre 1984 y 1993". In: M. Carrasco. Los derechos de los pueblos indígenas en Argentina. Buenos Aires: IGWIALLAKA HONHAT, Vinciguerra. pp. 63-190.

; STERPIN, Laura \& WEINBERG, Marina. 2006. "Entre la cooperación y la asistencia: un análisis de la incidencia del apoyo económico internacional en el movimiento indígena en Argentina”. VIII Congreso Argentino de Antropología Social, Salta, Argentina.

CASABURI, Gabriel \& TUSSIE, Diana. 2000. "La sociedad civil y los Bancos Multilaterales de Desarrollo". In: Diana Tussie (org.). Luces y Sombras de una nueva relación: el Banco Interamericano de Desarrollo, el Banco Mundial y la Sociedad Civil. Buenos Aires: Temas Grupo Editorial.

CASTRO MORA. 2008. ¿Reconocimiento o Asistencialismo? Antropología de la Negociación de un Proyecto de Turismo Cultural Indígena con Financiamiento del Banco Interamericano de Desarrollo. Tesis de Licenciatura en Ciencias Antropológicas, Universidad de Buenos Aires.

COMAROFF, John \& COMAROFF, Jean. 1992. Ethnography and the historical Imagination. Boulder: Westview Press, .

CONKLIN, Beth \& GRAHAM, Laura. 1995. "The Shifting Middle Ground: Amazonian Indians and Eco-Politics”. American Anthropologist, 97(4):695-710. 
CONTI, Viviana; TERUEL, Ana \& LAGOS, Marcelo. 1988. Mano de obra indígena en los ingenios de Jujuy a principios de siglo. Colección Conflictos y procesos de la Historia Argentina Contemporánea, n. 17. Buenos Aires: Centro Editor de América Latina.

CORACH, Daniel; SALA, Andrea \& MARINO, Miguel. 2005. "Contribución amerindia a la población actual de Argentina”. Revista Argentina de Antropología Biológica vol. 7, n. 1, AABRA.

CORDEU, Edgardo \& SIFFREDI, Alejandra. 1971. De la algarroba al algodón: movimientos milenaristas del Chaco Argentino. Buenos Aires: Juárez Editor.

DELEUZE, Gilles \& GUATTARI, Félix. 1998. Mil mesetas. Capitalismo y esquizofrenia. Madrid: Pre-textos.

DELRIO, Walter. 2005. Memorias de expropiación. Sometimiento e incorporación indígena en la Patagonia, 1872-1943. Buenos Aires: Ed. de la Universidad Nacional de Quilmes.

DELRIO, Walter \& LENTON, Diana. 2008. “¿Qué, para quiénes y según quiénes? Reparaciones, restituciones y negaciones del genocidio en la política indígena del estado argentino". III Jornadas de Historia de la Patagonia. Bariloche: Universidad Nacional del Comahue.

DUSSEL, Inés. 2003. "Foucault y la escritura de la historia: reflexiones sobre los usos de la genealogía”. Revista Educación y Pedagogía, Universidad de Antioquía, agosto.

ESCOLAR, Diego. 2003. Identidades emergentes y modos de producción de soberanía estatal en Cuyo. El debate Huarpe en la actualidad. Tesis Doctoral, Universidad de Buenos Aires.

FALASCHI, Carlos; SÁNCHEZ, Fernando \& SZULC, Andrea. 2005. "Políticas indigenistas en Neuquén: pasado y presente”. In: Claudia Briones (org.). Cartografías argentinas: políticas indígenas y formaciones provinciales de alteridad. Buenos Aires: Ed. Antropofagia. pp. 9-40.

FOUCAULT. Michel. 1991. "Questions of method”. In: G. Burchell; C. Gordon \& P. Miller (eds.). The Foucault Effect. Studies in Governmentality. Chicago: The University of Chicago Press. pp. 73-86. 
GORDILLO, Gastón. 1995. "La subordinación y sus mediaciones. Dinámica cazadora-recolectora, relaciones de producción, capital comercial y Estado entre los Toba del oeste de Formosa". In: H. Trinchero (org.). Economía doméstica y capital. Buenos Aires: Biblos.

GRÜNER, Eduardo. 2003. "La rama dorada y la hermandad de las hormigas. La 'identidad' argentina en Latinoamérica: ¿realidad o utopía?". In: Atilio Borón (org.). Filosofía política contemporánea. Controversias sobre civilización, imperio y ciudadanía. Buenos Aires: CLACSO. pp. 341-372.

HERNÁNDEZ, Isabel. 2003. Autonomía o Ciudadanía Incompleta: El Pueblo Mapuche en Chile y Argentina. CEPAL-ONU y Pehuén Ediciones.

IÑIGO CARRERA, Nicolás. 1984. Campañas militares y clase obrera. Chaco, 18701930. Buenos Aires: C.E.A.L., Colección Historia Testimonial Argentina.

1988. La violencia como potencia económica: Chaco 1870-1940. Colección Conflictos y procesos de la Historia Argentina Contemporánea, n. 11. Buenos Aires: Centro Editor de América Latina.

KINDGARD, Adriana. 2004. "Tradición y conflicto social en los Andes argentinos. En torno al Malón de la Paz de 1946”. Estudios Interdisciplinarios de America Latina y el Caribe E.I.A.L., vol. 15, n. 1: 165-185, Universidad de Tel Aviv.

LAZZARI, Axel. 2004. "Antropología en el Estado: el Instituto Etnico Nacional (1946-1955)”. In: F. Neiburg \& M. Plotkin (eds.). Intelectuales y expertos. La constitución del conocimiento social en la Argentina. Buenos Aires: Paidós. pp. 203-230.

\& Lenton, Diana. 2000. "Etnología y Nación: facetas del concepto de Araucanización”. Avá - Revista de Antropología, 1: 125-140, abril, Programa de Posgrado en Antropología Social, Universidad Nacional de Misiones y CONICET, Posadas. LENTON, Diana. 2001. "Debates parlamentarios y aboriginalidad: cuando la oligarquía perdió una batalla (pero no la guerra)”. Papeles de Trabajo, 9:7-30, Centro de Estudios Interdisciplinarios en Etnolingüística y Antropología, Universidad Nacional de Rosario y C.I.C.E.A.S., Rosario. 
. 2004. "Todos éramos desarrollistas...: la experiencia del Primer Censo Indígena Nacional”. Revista Etnía, vol. 46-47, Instituto de Investigaciones Antropológicas de Olavarría.

2005. De centauros a protegidos. La construcción del sujeto de la política indigenista argentina a través de los debates parlamentarios. Tesis de Doctorado en Ciencias Antropológicas, Universidad de Buenos Aires.

2008a. "La frontera, la guerra y la nostalgia: construcciones de la Argentina moderna como 'país sin indios"”. In: S. Villavicencio \& M. I. Pacecca. Representaciones de la nación, Estado y ciudadanía: hiatos y fisuras en la historia política de los conceptos. Buenos Aires: Ed. del Puerto. pp. 131-152.

2008b. "Políticas del Estado indigenista y políticas de representación indígena en la Argentina durante las décadas de 1960 y 1970”. Simposio: Estados Nacionales del Cono Sur, pueblos indígenas y políticas interétnicas (siglos XIX-XXI). Mendoza: CETYL, Universidad Nacional de Cuyo.

. 2008c. "Aboriginality, Memory and Struggle: The Malón de la Paz and the Genesis of Indigenous Militancy in Argentina". In: Oscar Chamosa \& Matthew Karush. The New Cultural History of Peronism, 1930-1966. Durham: Duke University Press.

\& LORENZETTI, Mariana. 2005. "Neoindigenismo de necesidad y urgencia: la inclusión de los Pueblos Originarios en la agenda del Estado neoasistencialista”. In: Claudia Briones (org.). Cartografías argentinas: políticas indígenas y formaciones provinciales de alteridad. Buenos Aires: Ed. Antropofagia. pp. 9-40.

LINS RIBEIRO, Gustavo. 2004. "Tropicalismo y europeísmo: modos de representar a Brasil y Argentina”. In: A. Grimson; G. Lins Ribeiro \& P. Semán (orgs.). La antropología brasileña contemporánea. Contribuciones para un diálogo latinoamericano. Buenos Aires: A.B.A. y Ed. Prometeo.

LOIS, Carla. 1998. El Gran Chaco argentino: de desierto ignoto a territorio representado. Un Estudio acerca de las formas de apropiación material y simbólica de los territorios chaqueños en los tiempos de consolidación del Estado-nación argentino. Tesis de Licenciatura en Geografía, Universidad de Buenos Aires. 
\& TRONCOSO, Claudia. 1998. "Integración y desintegración indígena en el Chaco: los debates en la Sociedad Geográfica Argentina (1881-1890)”. Primer Congreso Virtual de Antropología y Arqueología Ciberespacio, octubre. Organizado por Equipo NayA. Disponible en http://www.naya.org.ar/congreso

MASES, Enrique Hugo. 2002. Estado y cuestión indígena. El destino final de los indios sometidos en el fin del territorio (1878-1910). Buenos Aires: Prometeo libros/Entrepasados.

MASTRANGELO, Andrea. 2005. "Nuestro sueño es un mundo sin pobreza. Un estudio etnográfico sobre el Banco Mundial. Avá, Revista de Antropología, PPAS. UNAM. Misiones, 8:113-130.

OTERO, Hernán. 2004[1997]. "Investigando a investigadores del pasado. Estrategias teórico-metodológicas para el estudio de los censos nacionales de población en la Argentina moderna”. In: Catalina Wainerman \& Ruth Sautu (orgs.). La trastienda de la investigación. Buenos Aires: Lumiére.

PIMENTA, José. 2003. “A História oculta da Floresta. Imaginário, conquista e povos indigenas no Acre”. Revue Linguagens Amazônicas, 2:27-44.

QUIJADA, Mónica. 2000. "Introducción”; cap. 1 "El paradigma de la homogeneidad"; cap. 2 "Indígenas: violencia, tierras y ciudadanía”; y cap. 5 "Imaginando la homogeneidad: la alquimia de la tierra”. In: ; C. Bernand \& A. Schneider. Homogeneidad y Nación con un estudio de caso: Argentina, siglos XIX y XX. Madrid: Colección Tierra Nueva e Cielo Nuevo, CSIC.

RADOVICH, Juan Carlos. 1992. "Política indígena y movimientos étnicos: el caso mapuche”. Cuadernos de antropología, 4, Universidad Nacional de Luján.

RAGGIO, Liliana. 2003. "Evaluación de programas sociales desde una perspectiva cualitativa”. In: Javier Lindemboin \& Carla Danani (orgs.). Entre el trabajo y la política. Las reformas de las políticas sociales argentinas en perspectiva comparada. Buenos Aires: Biblos. 
RAMOS, Ana. 2005. "Trayectorias de Aboriginalidad en las comunidades mapuche del Noroeste de Chubut (1990-2003)”. Tesis Doctoral en Ciencias Antropológicas, Universidad de Buenos Aires.

RAMOS, Alcida. 1990. "Indigenismo de resultados". Série Antropologia, 100, Brasília. . 2009. "O indigenismo na montagem da Nação. Contrastes e convergências entre Brasil e Argentina”. Anuario Antropológico, en prensa.

RECALDE, Héctor. 1999. La salud de los trabajadores en Buenos Aires (1870-1910) a través de las fuentes médicas. Buenos Aires: Grupo Editorial Universitario, Biblioteca de Temas Argentinos.

ROSE, Nikolas. 1999. Powers of Freedom. Reframing Political Thought. Cambridge: Cambridge University Press.

ROSENZVAIG, Eduardo. 1986. Historia Social de Tucumán y del azúcar. Tomo 2: El Ingenio. San Miguel del Tucumán: Universidad Nacional de Tucumán.

RUTLEDGE, Ian. 1987. “La Economía azucarera en la Argentina. 1930-1943”. In: . La Tierra y la Mano de Obra en América Latina. México: FCE.

SERBÍN, Andrés. 1981. "Las organizaciones indígenas en la Argentina”. América Indígena, vol. XLI, n. 3:407-433, julio-septiembre, Instituto Indigenista Interamericano, México.

SIEDER, Rachel. 2004. Multiculturalism in Latin America: Indigenous Rights, Diversity and Democracy. Basingstoke and London: Palgrave Press.

TERUEL, Ana. 1991. "Regulación legal del trabajo en las haciendas, ingenios y plantaciones de azúcar en la Provincia de Jujuy, siglo XIX a mediados del siglo XX". In: Estudios sobre la historia azucarera argentina, vol.1. UNT, San Miguel de Tucumán.

TRINCHERO, Hugo. 2000. Los Dominios del Demonio. Civilización y Barbarie en las Fronteras de la Nación. El Chaco Central. Buenos Aires: EUDEBA. 
. 2005. "Estigmas del genocidio indígena en el cuerpo del Estado-nación". Revista Espacios, 32: 33-38, Facultad de Filosofía y Letras, Universidad de Buenos Aires, junio-julio.

ULLOA, Astrid. 2005. "Las representaciones sobre los indígenas en los discursos ambientales y de desarrollo sostenible.” In: Daniel Mato (org.). Políticas de economía, ambiente y sociedad en tiempos de globalización. Caracas: Facultad de Ciencias Económicas y Sociales, Universidad Central de Venezuela. pp. 89-109.

VALKO, Marcelo. 2007. Los indios invisibles del Malón de la Paz. De la apoteosis al confinamiento, secuestro y destierro. Buenos Aires: Ed. Madres de Plaza de Mayo.

VÁZQUEZ LABÁ, Vanesa. 2004. "La vulnerabilidad social de los/as asalariados/as citrícolas y sus familias en la provincia de Tucumán”. Lavboratorio. Estudios sobre cambio estructural y desigualdad social, año 5, n. 14:17-21, Facultad de Ciencias Sociales, UBA, otoño-invierno.

VILLALTA, Carla. 2001. ¿¿De quien son los niños pobres? El debate por la tutela estatal, religiosa o caritativa”. IV RAM / Reunión de Antropología del Mercosur, Curitiba, Brasil, 11 al 14 de noviembre de 2001.

WRIGHT, Pablo. 2003. "Colonización de la palabra, el espacio y el cuerpo en el Chaco argentino”. Horizontes antropológicos, Porto Alegre, año 9, n. 19:137-152, julio. Disponible en http://www.scielo.br/pdf/ha/v9n19/v9n19a05.pdf 


\section{Resumen}

La política indigenista argentina se vio comprometida desde los inicios de la Organización Nacional por el éxito hegemónico de la idea de la pronta extinción de los Pueblos Originarios en el territorio estatal. Esta idea se impuso a lo largo del siglo XX en el discurso político y en el sentido común ciudadano, pese a las frecuentes pistas en contrario ofrecidas por la praxis política -que incluyó desde continuidades en la acción militar expansiva o represiva, arduas de explicar, hasta la experiencia siempre leída como "positiva" de utilización de mano de obra aborigen en las agroindustrias regionales estratégicas, pasando por involucramientos políticos nuevos en una desconfiada base participativa, hacia el fin de siglo. Las tensiones derivadas de este esquema ideológico dieron a la política indigenista argentina un carácter inorgánico, errático y pleno de contradicciones, pese a lo cual es posible hallar continuidades y etapas de desarrollo de conceptos y tópicos que, no obstante su adhesión a contextos sociopolíticos determinados, perduran y decantan en el discurso indigenista actual. El siguiente es, entonces, un intento de des-cubrimiento de la genealogía de ciertos conceptos hoy vigentes en la política estatal argentina respecto a los Pueblos Originarios.

\section{Palabras clave}

Política indigenista, discurso político, aboriginalidad.

\section{Abstract}

Argentine policies towards Indigenous Peoples was challenged from the beginning of the period known as "National Organization" by the hegemonic success of the idea of their close extintion in the State territory. This idea was imposed through the XXth century in political discourse and in citizens' common sense, despite frequent signals in contrary, offered by political praxis -which included since continuities in expansive or repressive military actions, arduous to explain, up to the experience, always read as "positive", of the employment of Aboriginal force of labour in strategic regional agro-industries, passing through new engagements in a participatory political base, towards the end of the century. Tensions arising from this ideological scheme gave Argentine policies towards Indigenous an inorganic, erratic and full of contradictions character, despite which it is possible to find continuities and stages of development for concepts and topics that, notwithstanding its adherence to certain socio-political contexts, remain and leave traces in current "indigenist" speech. The following is thus an attempt to un-cover the genealogy of some existing concepts in Argentine State policy regarding Originary Peoples.

\section{Key words}

Indigenist policy, political discourse, aboriginality. 